\title{
ACCOUNT STATED RESURRECTED: THE FICTION OF IMPLIED ASSENT IN CONSUMER DEBT COLLECTION
}

\author{
Emanwel J. Turnbull ${ }^{* \dagger}$
}

INTRODUCTION

Since the 2008 financial crisis, state courts have been flooded with actions seeking to collect money from consumers. This inundation of claims has been accompanied by bad practices, ranging from defective (or sewer) service, to robo-signing. ${ }^{1}$ Cases have even emerged in which a single consumer was subjected to two successive claims for the same debt. ${ }^{2}$ Suits brought outside the limitation period have also become a problem. ${ }^{3}$ The debt buyers purchase tens of billions of dollars in debt every year, but

* International \& Comparative Law Fellow, University of Maryland Francis King Carey School of Law, Adjunct Professor, University of Baltimore Yale Gordon College of Arts \& Sciences; LL.M 2012, University of Maryland Carey School of Law; B.A. Hons. 2007, Oxford. Mr. Turnbull has presented at the annual conference of the Younger Comparativists Committee of the American Society of Comparative Law.

$\dagger$ This Article would not have been written without the time and encouragement of an outstanding consumer lawyer and clinical professor, Peter A. Holland. Thanks are also due to the participants of the Carey School of Law Junior Faculty Workshop for their helpful comments on this paper: Mark Graber, Max Sterns, Andrew Blair-Stanek, Shruti Rana, Mike Pappas and Sherri Keene; to my colleagues Lauren Lankford and Jasmine Elavia for their comments on early drafts, and to the staff of the Vermont Law Review. Several Maryland lawyers also provided comments on drafts of this paper. Their contributions were invaluable. Any errors are the author's.

1. "Sewer service" is the practice of private process servers falsely claiming to have served papers on individuals when they have simply thrown the papers away. "Robo-signing" is the practice of signing affidavits en-mass with no serious attempt to verify the correctness of the facts stated in the affidavit. See The Legal Aid Society Et. Al., Debt Deception: How Debt Buyers Abuse the LEGAL SYSTEM TO PREY ON LOWER-INCOME NEW YORKERS 6 (May 2010), available at http://www.nedap.org/pressroom/documents/DEBT_DECEPTION_FINAL_WEB.pdf; Peter A. Holland, The One Hundred Billion Dollar Problem in Small Claims Court: Robo-Signing and Lack of Proof in Debt Buyer Cases, 6 J. Bus. \& TECH. L. 259, 266, 268 (2011); e.g., Ray Rivera, Suit Claims Fraud by New York Debt Collectors, N.Y. TIMES, Dec. 30, 2009, http://www.nytimes.com/ 2009/12/31/nyregion/31debt.html; Martha Neil, Federal Judge Certifies Class In 'Sewer Service' Suit Against NY Debt Collection Law Firm, A.B.A. J., Sept. 12, 2012, available at http://www.abajournal.com/news/article/federal_judge_certifies_class_in_sewer_service_suit_against_n y_debt_collect/. However, sewer service has long been an issue in debt cases, particularly in New York. See DAVId CAPlovitz, Consumers In Trouble 200-201 (1974) (an empirical study, noting that 20\% of debtors interviewed were personally served, while court records indicated personal service in over $90 \%$ of cases).

2. E.g., The Legal AID Society, supra note 1, at 13 (discussing the case of a B.P. of Manhattan, who was sued twice by the same plaintiff, the first suit having been dismissed with prejudice); Capital Credit \& Collection Serv., Inc. v. Armani, 206 P.3d 1114, 1116-17 (Or. Ct. App. 2009) (finding that debt collector settled a debt and then instituted litigation on the same debt).

3. E.g., Andrew Martin, Old Debts That Won't Die, N.Y. TIMES, July 30, 2010, http://www.nytimes.com/2010/07/31/business/31 collect.html?pagewanted=all\&_r=0; FED. TRADE COMM'N, REPAiring A Broken System: Protecting CONSUMERS IN DEBT COLlECTION Litigation AND ARBITRATION 29 (July 2010) [hereinafter REPAiRING A BROKEN SYSTEM] ("Many consumer advocates and some judges expressed the view that some collectors regularly sue consumers on timebarred debts."). 
the rise of debt buying has been accompanied by increased consumer complaints. ${ }^{4}$ The high volume of claims and the abuse of consumers that accompanies them led the Federal Trade Commission (FTC) to declare the debt collection system "broken," consumers. While creditors usually attempt to collect debts without litigation, creditors still file a very large number of suits against consumers. For example, from 2009 to 2012, a group of fifteen debt-buying businesses filed over 131,000 such suits in Maryland. ${ }^{6}$ That is one suit for every fortyfour residents. ${ }^{7}$

This Article is about one feature of the collection claims "flood": 8 the resurrection of a 300-year-old doctrine, little-used in America since the 1950s. This Article calls that doctrine "implied account stated" and it can be found in collection actions around the country. ${ }^{9}$ Implied account stated is a cause of action, pled when a creditor sues to recover a debt. ${ }^{10}$

Implied account stated is one part of the wider action for an account stated, and to understand the implied form it is necessary to explain the account stated more generally. An "account stated" is an agreement, express or implied, between parties who have prior dealings ${ }^{11}$ that a particular sum is due from one to the other and a promise by the debtor to

4. Fed. Trade Comm'n, The Structure and Practices of the Debt Buying INDUSTRY 1, 7 (2013) [hereinafter STRUCTURE AND PRACTICES] (highlighting the Neilson Report, which states that $\$ 72.3$ billion in debt was purchased by debt buyers in 2008).

5. REPAIRING A BROKEN SYSTEM, supra note 3, at 1.

6. Peter A. Holland, Junk Justice: A Statistical Analysis of 4,400 Lawsuits Filed by Junk Debt Buyers in Maryland, LOY. CONSUMER L. REV. (forthcoming 2014).

7. In 2010, Maryland had an estimated population of 5,785,681. Table 1. Annual Estimates of the Resident Population for Counties of Maryland: April 1, 2010 to July 1, 2011, U.S. CENSUS BUREAU (Apr. 2012), http://www.census.gov/popest/data/counties/totals/2011/tables/CO-EST2011-01-24.xls.

8. Sam Glover, Has The Flood Of Debt Collection Lawsuits Swept Away Minnesotans' Due Process Rights?, 35 WM. Mitchell L. REV. 1115, 1116 (2009); Matthew Kish, Debt Cases Flood Courts, PORTLAND BUS. J. (2011), available at http://www.bizjournals.com/portland/print-edition/2011/ 02/25/debt-cases-flood-courts.html?page=all. A recent New York study showed that in some jurisdictions $90 \%$ of all civil filings were debt collection cases. NEW ECONOMY PROJECT, THE DEBT COLLECTION RACKET IN NEW YoRK: How the INDUSTRY Violates Due Process AND PERPETUATES ECONOMIC INEQUALITY 6 (2013), available at http://www.nedap.org/resources/documents/ DebtCollectionRacketNY.pdf.

9. See generally West Virginia: Complaint, Cach, LLC, v. Wagner, No. 07-C-2177, 2007 WL 5964644 (W. Va. Cir. Ct. Oct. 12, 2007); Complaint, Cach, LLC., v. Anthony, No. 07-C-2309, 2007 WL 5964653 (W. Va. Cir. Ct. 2007 Oct. 25, 2007); Pennsylvania: Cavalry Portfolio Servs., LLC., v. Mostyn, No. 2010-3233 (Pa. Ct. Com. Pl. Feb. 2011), available at http://www.nclc.org/images/pdf/ unreported/Calvary.pdf; Target Nat'l Bank v. Greiner, No. Cl-09-03069 (Pa. Ct. Com. Pl. Sept. 30, 2009), available at http://www.nclc.org/images/pdf/unreported/Target_Greiner.pdf; New York: Discover Bank v. Sura, No. CV-11-3421, 2012 WL 1450028, at*1-3 (Poughkeepsie City Ct. Apr. 26, 2012); Citibank (S.D.) N.A. v. Jones, 706 N.Y.S.2d 301, 302 (Nassau Cnty. Dist. Ct. 2000).

10. See cases cited supra note 9; See RESTATEMENT (SECOND) OF CONTRACTS $§ 282$ (1979) (stating that an account stated may be implied, and this may be binding on the parties).

11. Some jurisdictions say that the dealings must be a monetary nature. Toth v. Mansell, 566 N.E.2d 730, 734-35 (Ill. App. Ct. 1991); Rehmann v. Balduchi, 169 N.W.2d 894, 895 (Iowa 1969). 
pay the sum due to the creditor. ${ }^{12}$ This definition is necessarily broad because of the variation between different jurisdictions about the nature of account stated. For example, some jurisdictions treat it as a distinct cause of action, which does not create new liability, ${ }^{13}$ but can be used independently of any other cause of action. ${ }^{14}$ Others hold that account stated does nothing more than create a presumption that the stated amount is correct. ${ }^{15}$

So, account stated, in its broadest sense, has two elements:

\section{There must be some pre-existing debt or obligation of payment; ${ }^{16}$ and}

2. The debtor must assent to the sum owed and promise to pay, either:

(a) Expressly, or

(b) Implicitly, by a failure to object to a statement of account within a reasonable time. ${ }^{17}$

12. This definition is a synthesis of those found in various sources: 1A C.J.S. Account Stated $\S 1$ (2005); 1 AM. JUR. 2D Accounts and Accounting $\S 26$ (2005); RESTATEMENT (SECOND) OF CONTRACTS $§ 282$ (1979); see infra the cases from New York and Maryland cited in Part II.

13. E.g., Balt. Cnty. v. Archway Motors Inc., 370 A.2d 113, 118 (Md. Ct. Spec. App. 1977) ("An account stated cannot be made the instrument to create an original liability; it merely determines the amount of the debt where liability previously existed." (quoting Conley v. Nat'l House Furnishing Co., 11 N.E.2d 828, 830 (Ill. App. Ct. 1937))). This rule was also present historically. See JOSEPH Chitty, Jr., A Practical Treatise on The Law of Contracts, Not Under Seal; AND upon The UsuAl DEFEnCES to ACTIONS THEREON 648-48a (Tompson Chitty eds., 6th Am. ed. 1844) [hereinafter CHITTY 6TH] ("There must however have existed some demand against the defendant, or some prior transactions between the parties in respect of which the account was stated, and a mere special agreement to pay a sum of money cannot be converted into an account stated."); JOSEPH CHITTY, JR., A Practical Treatise on The Law of Contracts, Not Under SEAL; AND upon The Usual Defences to ACtions Thereon 197, 199 (Francis J. Troubat ed., 3d Am. ed. 1834) [hereinafter CHITTY 3D] (to similar effect).

14. E.g., Archway, 370 A.2d at 117 (account stated limited to cases where there is a preexisting debt); Lyell v. Walbach, 75 A. 339, 341 (Md. 1909) (holding that account stated is an independent cause of action); Jones, 706 N.Y.S.2d at 302 (to similar effect).

15. For example, Florida uses presumption language. First Union Discount Brokerage Servs. v. Milos, 997 F.2d 835, 841 (11th Cir. 1993). One Federal District Court, applying New York law, also used the language of presumption to explain account stated: Am. Home Assurance Co. v. Instituto Nacional de Reaseguros, No. 88-Civ.-0917, 1991 WL 4461, at*3 (S.D.N.Y. Jan. 10, 1991).

16. Archway, 370 A.2d at 118 ("[T]here can be no liability on an account stated if liability did not previously exist.”); Gurney, Becker \& Bourne, Inc. v. Benderson Development Co., 394 N.E.2d 282, 283 (N.Y. 1979) ("[A]n account stated cannot be made the instrument to create liability when none exists."); Greer Limestone Co. v. Nestor, 332 S.E.2d 589, 592 (W. Va. 1985) (“[W]here persons who have had previous transactions of a monetary character agree that the account representing the transactions and the balance shown are correct, and the debtor expressly or impliedly promises to pay such balance, the account thereby becomes an account stated." (quoting Hoover Dimeling Lumber Co., v. Neill, 87 S.E. 855,855 (W. Va. 1916))).

17. Archway, 370 A.2d at 118 ("[U]nder appropriate circumstances, a failure within a reasonable time to object to the correctness of a stated sum may be regarded as an admission of liability."); Gurney, Becker \& Bourne, Inc., 394 N.E.2d at 282 (N.Y. 1979) (“[A]n account which has been rendered and to which no objection has been made within a reasonable time should be regarded as admitted by the party charged as prima facie correct[.]"); Frederic A. Potts \& Co. v. Lafayette Nat'1 Bank, 199 N.E. 50, 52-53 (N.Y. 1935) ("[P] ursuant to the custom of banking, which custom was well known to the plaintiff, there was delivered to plaintiff a full and complete monthly statement of its 
Implied account stated occurs in situation 2(b): where a debtor fails to object to a statement in a timely manner.

This Article could begin with a doctrinal question: is this "implied account stated" a contract implied in fact, a quasi-contract, or just an evidentiary presumption? This is a question that will be reached in Part III. However, the more important question is larger and more practical: when can account stated be used to collect consumer debts? Account stated undeniably is used to collect consumer debts. ${ }^{18}$ This collection is particularly reliant upon the implied form of account stated. A New York court went so far as to say that "the raison d'etre of account stated is the assumption that the debtor's failure to dispute an account rendered to the debtor implies the debtor's agreement to the terms of the account." ${ }^{, 19}$ While this Article will argue that account stated should not be used in this way, the court's interpretation is undoubtedly a true statement about current practice. ${ }^{20}$ Lawyers representing consumers have written that account stated frequently appears in debt collection pleadings. ${ }^{21}$ The National Consumer Law Center's manual on consumer debt collection actions cites dozens of consumer debt collection cases in various jurisdictions in which account stated was at issue. ${ }^{22}$ In New York and elsewhere, implied account stated can be used to limit the amount and type of evidence needed to obtain a judgment against a consumer. ${ }^{23}$ The evidence-reducing quality of account stated is particularly important in uncontested cases to establish the proof

account" and that said statements "were duly received by plaintiff and retained by it." (internal quotation marks omitted)). But see Price Hill Colliery Co. v. Pinkney, 122 S.E. 434, 436 (W. Va. 1924) (“"The rule that an account rendered and retained for a long time without objection becomes an account stated is, as a general proposition, inapplicable in... West Virginia, except as between merchant and merchant, and principal and agent."' (quoting McGraw v. Traders' Nat'l Bank, 63 S.E. 398, 398 (W. Va. 1908)).

18. Jones, 706 N.Y.S.2d at 301; Jaramillo v. Portfolio Acquisitions, LLC, No. 14-08-00939CV, 2010 WL 1197669, at*7 (Tex. App. Mar. 30, 2010) ("a cause of action for an account stated is the proper tool for credit card collection.").

19. Jones, 706 N.Y.S.2d at 302.

20. E.g., Am. Express Centurion Bank v. Cutler, 916 N.Y.S.2d 622, 623 (App. Div. 2011) ("An agreement may be implied where a defendant retains bills without objecting to them within a reasonable period of time, or makes partial payment on the account.").

21. E.g., Glover, supra note 8, at 1121; Peter A. Holland, Defending Junk-Debt-Buyer Lawsuits, 43 Clearinghouse Rev. 12, 16 (2012); Clinton Rooney, Defense of Assigned Consumer Debts, 43 Clearinghouse Rev. 542, 545 (2010); see cases cited infra, Part I.B.1.

22. National Consumer law Center, Collection ACtions: Defending Consumers AND THEIR ASSETS 86-90 (2011 \& Supp. 2013).

23. Jones, 706 N.Y.S.2d at 303. E.g., Discover Bank v. Sura, No. CV-11-3421, 2012 WL 1450028, at *3 (Poughkeepsie City Ct. Apr. 26, 2012) ("Plaintiff does not have to submit a signed copy of an agreement in order to prevail on a motion for summary judgment based upon the account stated ...."). 
necessary to obtain an uncontested judgment. Most consumers do not defend debt collection suits. ${ }^{24}$

The resurrection of account stated in debt collection has presented a significant challenge to lawyers and judges. Account stated is an unfamiliar cause of action and even lawyers experience confusion about its exact meaning. One Maryland judge believed that "account stated" meant simply a credit card statement. ${ }^{25}$ Lawyers and judges are uncertain of its nature and even its continued existence. ${ }^{26}$ It is perhaps this unfamiliarity that causes account stated to appear even if contrary to established precedent; as noted below, account stated is pled in West Virginia cases, but implied account stated is clearly limited in West Virginia to mercantile and agency relationships. $^{27}$

This evidence-reducing quality is also important to the recent flood of collection litigation. One of the driving forces of the flood is the secondary debt market. $^{28}$ Large numbers of collection actions are brought by businesses that purchase defaulted consumer debts from original creditors such as banks. ${ }^{29}$ The Federal Trade Commission investigated the debt buying industry because of concerns about some debt buyers' practices. ${ }^{30}$ The Commission's findings give insight into the particular value of account stated for debt buyers. Debt buyers purchase large numbers of debts in "portfolios." 31 Each portfolio comes with a data file of basic information

24. RePAiring a BROKEn SyStem, supra note 3, at 7; Mary Spector, Debts, Defaults and Details: Exploring the Impact of Debt Collection Litigation on Consumers and Courts, 6 VA. L. \& Bus. REV. 257, 288 (2011) (concluding that only 20\% of consumers attempted to respond to lawsuits in a sample of collection cases); THE LEGAL AID SOCIETY, supra note 1, at 9 (finding that only $10 \%$ of consumers answered debt collection complaints). Consumers are even less likely to respond to suits today than they were in 1967. CAPLOVITZ, supra note 2, at 215 (stating 19\% of debtor-defendants in three cities studied appeared in court to defend themselves).

25. Interview with Anonymous Judge, Dist. Ct. Md. (2011) (on file with author).

26. One attorney who represents defendants in collection actions argues that account stated was abolished in 1984 with the abolition of common law pleading in Maryland, and states that this argument is accepted by some judges and rejected by others. (Comments on earlier draft, on file with author).

27. See infra Part I.B.1.

28. STRUCTURE AND PRACTICES, supra note 4, at i (explaining that the FTC chose to study the debt buying industry because its appearance has been the major change in the debt collection field in recent years and has been accompanied by increased consumer complaints to the FTC).

29. Jessica Silver-Greenberg, Boom in Debt Buying Fuels Another Boom-in Lawsuits, WALL ST. J., Nov. 28, 2010, http://online.wsj.com/article/SB1000142405270230451070457556221291 9179410.html. See Holland supra note 21, at 12 (commenting that one attorney acting for a debt buyer in Maryland filed 130 complaints on a single day another debt-buyer filed more than 7000 cases in two months).

30. Structure AND PRACTiCes, supra note 4, at i (relying upon data from nine very large debt buyers that resell some of the debts they purchase, so the report may not reflect the practices of smaller debt buyers who buy debts several times removed from the original creditor). Id. at 7 .

31. See Repairing A Broken System, supra note 3, at 7 (understanding that the large number of debts purchased by debt buyers lead to collection actions). 
about each individual debtor, but rarely includes documents. ${ }^{32}$ If debt buyers require copies of documents, they have a limited time to ask for them and may have to pay extra for each individual document. ${ }^{33}$ Further, debt buyers often sell debts to other debt buyers, so that the business that sues to recover the debt may be several steps removed from the original creditor. ${ }^{34}$ The debt buyer who sues must request documents through each previous buyer in the chain back to the original creditor, and the documents must come back down through the chain in the same manner. ${ }^{35}$ Presenting documentary evidence of a debt can be expensive for debt buyers in administrative resources, time, and money. In some cases, it may be impossible because time to request documents has expired. ${ }^{36}$

Implied account stated is useful to debt buyers because it does not require proof of the original contract between the consumer and the original creditor. ${ }^{37}$ Instead, it requires evidence of the "rendition of account" (sending an account statement). ${ }^{38}$ This could be as little as a copy of the last statement of account sent to the consumer, when combined with the allegation that an account existed and no objection was made to the statement. Implied account stated allows plaintiffs, debt buyers in particular, to collect on inadequately documented debts. An inquiry into precisely why documentation is difficult to obtain is beyond the scope of this Article. However, mortgage foreclosure cases offer obvious parallels with problems of inadequate documentation. ${ }^{39}$ The lack of documents in those cases is a symptom of the way mortgages were traded on the secondary debt market. ${ }^{40}$

32. Structure AND PRACTiCEs, supra note 4, at 34-35.

33. Id. at $39-40$.

34. See id. at 19 (describing the sale of debt to secondary debt buyers).

35. See id. at C-10 ("Subsequent purchasers of the consumer debt accounts were generally prohibited from directly contacting the credit issuer for document copies. They were required instead to make such requests through the initial debt buyer, who would then contact the credit issuer and request document copies.").

36. See id. at C-12 ("Many contracts specified a date beyond which the credit issuer was no longer obligated to provide any account documents to the debt buyer. This date was often set at two to three years following the date of sale.").

37. See Capital One Bank (USA), N.A. v. Denboer, 791 N.W.2d 264, 267, 278 (Iowa Ct. App. 2010) (holding that Capital One was only required to produce the consumers' account statements because "'the original items' are not a necessary prerequisite to obtaining a default judgment.").

38. Id. at 278 .

39. See generally James Geoffrey Durham, Avoiding a Lawyer's Race to the Foreclosure Bottom: Some Advice to Lawyers for Lenders and Borrowers on their Roles in Foreclosure Litigation, 32 N. ILL. U. L. REV. 419 (2012) (discussing the ethical obligations of lawyers representing borrowers facing disclosure).

40. See Victoria V. Corder, Note, When Securitization Complicates the Issue: What Are the Homeowner's Defenses to Foreclosure, 16 WASH. \& LEE J. CIVIL RTS. \& Soc. JusT. 229, 315 (2009) (giving examples of lack of documentation in cases involving mortgages traded on the secondary market). 
This Article will present three arguments against the use of implied account stated in consumer collections: (1) that implied account stated has historical origins in the practices of merchants, but that in the nineteenth century those origins were disregarded and that implied account stated is doctrinally impermissible in some states in light of their particular reaction to that expansion; (2) implied account stated is inappropriate in policy terms because it places a substantial burden upon consumers and has an evidence reducing quality; and (3) implied account stated is inconsistent with principles of modern contract law when applied to consumer defendants.

Part I will set out the history of account stated, from English law to the modern law of three states: West Virginia, New York, and Maryland. West Virginia is a special example, in which the state courts long ago held against the use of implied account stated in consumer-like cases. ${ }^{41} \mathrm{New}$ York is a counter example, in which implied account stated has been accepted as an appropriate cause of action in consumer collection actions. ${ }^{42}$ Maryland represents the middle ground; its caselaw has neither accepted nor rejected implied account stated in these actions. ${ }^{43}$ In all three jurisdictions, however, account stated can be found as a cause of action in trial-level consumer collection pleadings, regardless of these doctrinal differences. In states like Maryland, the courts are faced with both doctrinal and policy questions about the use of account stated.

Part II will argue that implied account stated, even if it is doctrinally permissible, should not be used in collection actions for simple policy reasons: account stated restricts the ability of consumers to demand proof that they owe the debt in question, limits the ability of the court to inquire into the underlying agreement, and imposes an unfair burden on consumers while relieving businesses of a burden, which modern technology makes them easily able to bear.

Part III will argue that implied account stated is inconsistent with the principle that silence and inaction do not give assent. Account stated is a cause of action based on an agreement between debtor and creditor, like an accord and satisfaction. ${ }^{44}$ Implied account stated has become analogous to a quasi-contract because it relies on the legal fiction that the debtor has

41. See infra Part I.B.1.

42. See Citibank (S.D.), N.A. v. Brown-Serulovic, 948 N.Y.S.2d 331, 332 (App. Div. 2012) (holding that the plaintiff consumer failed to "establish its entitlement to judgment as a matter of law on its cause of action" based on implied account stated theory).

43. See Balt. Cnty. v. Archway Motors Inc., 370 A.2d 113, 118 (Md. Ct. Spec. App. 1977) (recognizing the existence of an account through inference, but denying plaintiff's claim on accounts stated due to the non-existence of underlying debt); see also cases cited infra Part I.B.3.

44. RESTATEMENT (SECOND) OF CONTRACTS § 282 (1979). 
agreed and promised to pay the debt. ${ }^{45}$ Implied account stated has historical origins as an agreement implied in fact-as a rule amongst merchants. That original rule is consistent with modern contract principles, but the expansion of implied account stated to consumers brings it into conflict with contractual principles.

These problems call for a change to account stated. I will conclude that account stated must be brought back to reality and to conformity with its underlying principles. Account stated should be implied only where there is evidence sufficient to imply, as a matter of fact, that assent was intended. Silence and inaction should be insufficient except in the circumstances from which the original rule arose: the existence of established trade practices or previous dealings. These changes would remove a theoretical inconsistency from the law. More importantly, they would prevent the abuse of account stated as a vehicle for collection when the plaintiff cannot or will not present adequate evidence to succeed on a breach of contract claim. Narrowing account stated, whether it is through legislation or judicial action, can protect consumers, relieve courts of the burden of grappling with this archaic cause of action, and can mend the broken system, at least in one small part.

\section{THE History OF ACCOUNT STATED}

This Part will set out the history of account stated in general, implied account stated in particular, and survey developments in account stated in three states: New York, West Virginia, and Maryland. It is important to distinguish between "account stated" and "implied account stated" in order to follow their history. Implied account stated, as it is called in this Article, is a very specific rule with origins distinct from account stated.

Account stated has not attracted a great deal of attention from legal historians. A short article by the English legal historian S.F.C. Milsom links account stated to the action for debt on account. ${ }^{46}$ In the fourteenth century, actions for debt on account - those debts that arose from a series of cross transactions - could result in a court ordered accounting. At this time, the practice amongst London merchants was to conduct informal settlements of accounts amongst themselves. ${ }^{47}$ These informal settlements appear as

45. Juli Loden, The Earth is Not Flat and "A Quasi Contract Is Not A Contract At All”, 11 TRANSACTIONS: THE TENN. J. OF BUS. LAW 167, 187 (2010); see William R. ANSON, PRINCIPLES OF THE LAW OF CONTRACTS 325 (O.W. Aldrich ed., Am. ed. 1880) (stating that a legal relationship persists even though the original form no longer exists).

46. S.F.C. Milsom, Studies in the History of the COMmon Law, 133 (1985). Account stated and the action on account are sometimes still confused today. E.g., Nat'l Check Bureau v. Buerger, No. 06-CA-008882, 2006-Ohio-6673, ๆ 20 (Ct. App. Dec. 18, 2006).

47. MiLsOM, supra note 46, at 137. 
concessit solvere actions in the local courts of medieval London. ${ }^{48}$ This customary form of action allowed Londoners to sue without setting out the underlying transactions that were the foundation of the debt. ${ }^{49}$ What we now call account stated was then differentiated from an ordinary action based on a formal accounting by a third party: account stated relied on an informal accounting between the parties only. This informal accounting was eventually distinguished in the Common Law courts by the phrase insimul computassent. ${ }^{50}$ Samuel Stoljar agreed with Milsom's view: "To speak of an account stated is as yet not to name an action, but rather to describe an activity, namely that the parties voluntarily accounted between themselves." ${ }^{, 51}$ Account stated arrived in the legal thought of later centuries through that concept: two parties, striking a private agreement about the debts owed to each other.

Account stated became a branch of assumpsit, ${ }^{52}$ the ancestor of modern actions based on contract. An assumpsit action pleading an account stated relied on the same informal reconciliation of accounts, insimul computassent, as before: the parties had voluntarily struck an account together. ${ }^{53}$ Account stated was at first objected to on the grounds of the emerging doctrine of consideration, but these objections failed. ${ }^{54}$ Account stated came to be distinguished doctrinally from other similar pleadings because it affected a kind of novation; a suit for account stated was not based upon the underlying transaction, but based on the informal accounting. ${ }^{55}$ This pleading became one of the "common counts" usually pled in the alternative in actions for debt. ${ }^{56}$ The common counts were implied contract and quasi-contract theories, most of which are still in use

48. Id.

49. Id. at 136 ("[T] things sold, without setting them out in detail; and, since the defendant could wage his law, it seems that this sufficiency of a general reference to the underlying transactions was the only advantage the creditor normally gained.") Milsom goes on to note, however, that in one particular case, the customary action could allow the recovery of debt accrued abroad, which were not normally actionable. Id.

50. Id. at 141 ("[A]lthough an accounting just between the parties is at first more commonly denoted by saying that the defendant computavit cum the plaintiff, insimul computaverunt or insimul computassent slowly gains in favour until a prothonotary in 1464 describes it as a standard form to distinguish the case from that of the account before auditors.").

51. Samuel Stoljar, What Is Account Stated?, 4 SydNEY L. REV. 373, 373 (1964).

52. J.H. BAKER, AN INTRODUCTION TO ENGLISH LEGAL HISTORY 191 (1973).

53. Id. ("A second device was appropriate where tradesmen or merchants had accounted with each other or with customers and an agreed total debt was acknowledged.").

54. Stoljar, supra note 51 , at 374-75.

55. Id. at 374 ("In this way, also, account stated begins to mark itself off from other indebitatus counts, in that the present claim is not for money lent, or money had and received, or goods sold and delivered, but is a claim in respect of 'several matters' that are 'reduced to a sum certain'...." (quoting Howes v. Savill, Cro. Car. 116 (U.K., 1689)).

56. Id. at 373 . 
today and familiar to lawyers, for example, money had and received, and quantum meruit.

While account stated enjoyed controversy as a means of settling debts in the eighteenth century, ${ }^{57}$ the nineteenth century is the period of greatest interest for the purposes of this Article. Account stated was received into American colonial law with the rest of English law, and it was still in use at the turn of the nineteenth century. It was said to be a rule of Chancery applying particularly to merchants. ${ }^{58}$ Toward the end of the nineteenth century, account stated enjoyed a great expansion. By the beginning of the twentieth century it was regarded, at least in some states, as an independent common law cause of action, applicable beyond mercantile relationships. Despite this expansion, account stated fell out of use in the early twentieth century, until its recent resurrection.

The old limitation of account stated - to merchant-merchant dealingsgoes to the doctrine's core. By examining this requirement and its ostensible demise, this Part will show: (1) that the "merchant requirement" was not a prerequisite for any account stated, only an element of the implication of an account stated; (2) cases often said to have removed the merchant requirement are flawed because they treat the requirement as a prerequisite to all account stated actions, rather than an element of implication; and (3) the ostensible removal of account stated is not uniform between states.

\section{A. A Rule Between Merchants}

The history of account stated presented above traces the history of a concept; the idea that a private accounting accompanied by a promise to pay gives rise to an action in some way independent of the underlying transactions. These are based upon an actual accounting and agreement to pay. This takes us far from the raison d'etre of account stated today: the rule that retention without objection of a statement of account equates to an assent and promise to pay. This rule has come, for practical purposes, to eclipse the rest of the account stated. This section traces the origin and development of implied account stated.

Some early American cases and writers trace account stated back to Sherman v. Sherman in $1692 .{ }^{59}$ Sherman said that "amongst merchants it is looked upon as an allowance of an account current, if the merchant that

57. See Stoljar, supra note 51, at 377-78 (discussing claims that were representative of late eighteenth century account stated cases).

58. Freeland v. Heron, Lenox \& Co., 11 U.S. (7 Cranch) 147, 151 (1812).

59. Sherman v. Sherman, (1692) 23 Eng. Rep. 276, 276 (Ch.). E.g., Frank C. Haddock, The Account Stated, 22 CENT. L.J. 76, 76 (1886). 
receives it does not object against it, in a second or a third post." ${ }^{, 60}$ In modern terms, merchant custom held that a statement of account sent out and received, but not objected to within a reasonable time - a period set by merchant practices - was accepted as correct. ${ }^{61}$

While Sherman has been identified as the earliest account stated case, it does not use the expression and appears to be an action for a formal accounting. The expression "account stated" is found in Willis v. Jernegan:

[T]here is no absolute necessity that it should be signed by the parties who have mutual dealings, to make it a stated account, for even where there are transactions, suppose between a merchant in England and a merchant beyond sea, and an account is transmitted here from the person who is abroad, it is not the signing which will make it a stated account, but the person to whom it is sent, keeping it by him any length of time, without making any objection, which shall bind him, and prevent his entering into an open account afterwards. ${ }^{62}$

Both Jernegan and Sherman identify the implication of an account stated as a rule that applies between merchants. ${ }^{63}$ In Tickel $v$. Short, this limitation came to be a part of the doctrine; account stated is expressed as a rule of chancery and "of merchants." ${ }^{64}$ This description is repeated in Freeland $v$ Heron, an early United States case of an account stated:

When one merchant sends an account current to another residing in a different country, between whom there are mutual dealings, and he keeps it two years without making any objections, it shall be deemed a stated account, and his silence and acquiescence shall bind him. [A]t least so far as to cast the onus probandi on him. $^{65}$

This early string of cases sees a development, from the mercantile custom in Sherman to an explicit rule of equity, limited to particular persons (merchants) and in particular relationships (mutual dealings). In the early-

60. Sherman, 23 Eng. Rep. at 276.

61. Haddock, supra note 59 .

62. Willis v. Jernegan, (1741) 26 Eng. Rep. 555, 555 (Ch.).

63. Lord Hardwicke went on to discuss banks and their customers, speaking of record books banks gave to customers and vouchers kept for transactions. This discussion was quoted in Shepard v. Bank of Missouri to support the expansion of account stated to non- merchants. Shepard v. Bank of Mo., 15 Mo. 143, 152 (1951). However, Hardwicke's comments do not relate to modern consumer-bank dealings. The banking system was still emerging in England and banks were still largely commercial. See generally T.S ASHTON, AN ECONOMIC HISTORY OF ENGLAND: THE $18^{\mathrm{TH}}$ CENTURY (1955).

64. Tickel v. Short, (1750-1751) 28 Eng. Rep. 154, 154 (Ch.).

65. Freeland v. Heron, Lenox \& Co., 11 U.S. (7 Cranch) 147, 151 (1812). 
nineteenth century, it can be stated with fair certainty that account stated would not have applied in a consumer action unless - perhaps - there was express assent. ${ }^{66}$ All of these early cases involved the implication of assent by a mercantile debtor.

Modern treatises reflect the expansion of implied account stated from merchants to others in the nineteenth century ${ }^{67}$ Generally, the treatises say that account stated applies to everyone and that the limitation to merchants in the early cases has been abandoned. For example, Corpus Juris Secundum (CJS) says, "[t] he doctrine of account stated generally extends to all cases where the relation of debtor and creditor exists." the abandonment of the merchant requirement to cases ranging from the late nineteenth to early twentieth centuries.

CJS, for example, refers to a California case, Hemenover v. Lynip, ${ }^{69}$ which in turn cites an American Decisions note on account stated and a New York case, Stenton v. Jerome. ${ }^{70}$ Stenton itself does not refer to the merchant requirement. Hemenover notes the expansion of account stated beyond merchants as though it were already a settled matter, but it is primarily concerned with the prior debtor-creditor relationship requirement. Hemenover expresses doubt about the reach of the implication of account stated:

[I]t was never intended that through the mere means of sending out a claim that thereby a legal and recoverable demand might be created unless the adverse party made prompt and effectual denial. The law was intended to preserve and protect legitimate demands but not to create obligations independent of prior indebtedness. $^{71}$

On the basis of cases like Stenton and Hemenover, our treatises present unanimity between states about the law on account stated. However, the

66. Treatises of the day are primarily interested in express account stated. E.g., ANSON, supra note 45 (stating that an admission of debt implies a promise to pay); CHITTY 3D., supra note 13, at 19899 (claiming that for a plaintiff to recover under account stated when consideration is not proven, the account must be unqualifiedly acknowledged); CHITTY 6TH, supra note 13, at 649-50 (providing examples of express assent to an amount due); JOSEPH CHITTY, JR., A TREATISE ON THE LAW OF CONTRACTS, AND UPON THE DEFENCES TO ACTIONS THEREON 962, 965 (9th Eng. ed. 1874). See generally JOHN WiLLIAM SMITH, THE LAW OF CONTRACTS (William Henry Rawle \& George Sharswood eds., 6th Am. ed. 1878) [hereinafter SMITH 5TH] (not mentioning implied account stated at all).

67. See, e.g., 1A C.J.S. Account Stated $\S 2$ (2005) (understanding that account stated now extends to all cases where the relation of creditor and debtor exists).

68. 1A C.J.S Account Stated $\S 3$.

69. Hemenover v. Lynip, 290 P. 1089, 1091 (Cal. Dist. Ct. App. 1930).

70. Stenton v. Jerome, 54 N.Y. 480 (1873).

71. Hemenover, 290 P. at 1092. 
expansion of account stated was not uncontroversial in its time. ${ }^{72}$ Additionally, the cases cited as abandoning the merchant requirement do not clearly articulate that the merchant requirement was actually at issue. A useful example is the New York Court of Appeals decision in Rodkinson $v$. Haeker. ${ }^{73}$ In the case of an attorney suing his client upon an account stated, the court interpreted the "merchant and merchant" requirement as an element of the account stated generally, not a requirement for implied account stated. ${ }^{74}$ It was not necessary for the court to consider what was or was not a requirement for the implication of assent because the facts of the case were that the client had expressly promised to pay the debt. ${ }^{75}$ In these circumstances, the court addressed the issue of whether an attorney's client can promise to pay his debt of attorneys' fees. ${ }^{76}$

Considered in this light, it is unsurprising that the court held in the affirmative. ${ }^{77}$ Many expansion cases seem to have concerned relations between attorneys and clients. ${ }^{78}$ It seems only "common sense"-as it did to the court in Shepard v. Bank of Missouri-that anyone could promise to pay a debt they had already incurred. ${ }^{79}$ However, the courts in these cases were rejecting a straw man: they read the "merchant requirement" as wider than it was, or they confused account stated as a general theory of liability with the specific rule of implied account stated. ${ }^{80}$ The courts treated it as a

72. Haddock questioned the wisdom of the expansion:

$[\mathrm{I}] \mathrm{t}$ is a question whether the old reasoning may not be better entitled to respect than the more lax logic of modern times. Among merchants, accounts are supposed to be closely looked after at frequent intervals, but among business classes not mercantile debits and credits are mutually passed and bills rendered with a degree of attention depending largely upon the occupation of the parties.

Haddock, supra note 59; C.f. Doctrine of Account Stated-Between Whom it Applies, 5 VA. L.J. 678, 678 (1881) (discussing Anding v. Levy, 57 Miss. 51, 63 (1879), and collecting various cases on the issue, noting the divergence of opinion).

73. See generally Rodkinson v. Haecker, 162 N.E. 493 (N.Y. 1928).

74. Id. at 495 .

75. Id.

76. Id.

77. Id. at 496 .

78. E.g., Harris v. Drenning, 168 P. 1106, 1108 (Kan. 1917); Crane v. Stansbury, 161 P. 7, 9 (Cal. 1916); Gruby v. Smith, 13 Ill. App. 43, 44-5 (1883); Attorney and Client-Does Doctrine of Account Stated Apply?, 27 Mich. L. REV. 571, 571 (1929) (citing Griffith v. Hicks, 233 S.W. 1086, 1087 (Ark. 1921)). But see Ida Cnty. Savings Bank v. Johnson, 136 N.W. 225, 226 (Iowa 1912) (involving a bank); Ault v. Interstate Sav. \& Loan Ass'n., 47 P. 13, 14 (Wash. 1896) (involving an insurance company).

79. Shepard v. Bank of Missouri, 15 Mo. 143, 151 (1851) ("[T]here is no reason why the same doctrine should not prevail between any other persons, with whom are accounts current or accounts of transactions in the ordinary course of business."). After further discussion, the court described the rule as "founded in common sense, and is in accordance with the common course of human experience." Id. at 152 .

80. Ault, 47 P. at 15; Gruby, 13 Ill. App. at 45. 
prerequisite of any account stated rather than as a requirement for an implication of assent. ${ }^{81}$

While the expansion cases lack precision, later courts, as in Hemenover, accepted their reasoning and thought the merchant requirement had been abandoned for both express and implied accounts stated. ${ }^{82}$ Courts in states that have explicitly accepted the expansion are unlikely now to abandon it because of its problematic foundations, which are ancient history for trial judges.

Despite the loss of the merchant requirement and the consequent expansion of account stated into new territory, the action generally fell into disuse after the 1920s. In 1930 it was thought an archaic doctrine, ${ }^{83}$ and by 1960 it had reached a low point. Between 1960 and 1970, only 395 cases mentioning account stated were reported, compared to 847 at its peak in the decade between 1910 and 1920. In the same decade, 1,360 cases mentioned quantum meruit. ${ }^{84}$ Taking the example of Maryland, twenty-eight cases mention account stated after 1951. Only one case discusses account stated in any detail $;^{85}$ the others simply mention that it was pled. ${ }^{86}$

From the 1950s until the 1990s, account stated was an obscure cause of action. When the courts were faced with it, they often had to refer to treatises to find the law, ${ }^{87}$ and it is probably fair to say that lawyers largely $47 \mathrm{P}$. at 15

81. However, other cases more clearly abrogate the merchant rule that they rejected. E.g., Ault,

The old decisions, to the effect that this rule applied only to transactions between merchants, have become obsolete; and it is now held to apply to all classes, uninfluenced by their relation to each other, except that such relation will be taken into consideration in determining as to what is a reasonable time...."

Id.

82. See Hemenover v. Lynip, 290 P. 1089, 1092 (Cal. Dist. Ct. App. 1930) (understanding that account stated no longer just applies to merchant law).

83. Edmund O. Belsheim, The Old Action of Account, 45 HARV. L. Rev. 466, 466, 471 (1931) (tracing account stated to fourteenth century Year Book reports).

84. Based on searches performed using LexisNexis "all state and federal" cases database. This is, of course, a straw poll. Cases that reach the law reports are not a very accurate reflection of suits filed or tried, however, for these purposes, they illustrate the fall of account stated into relative obscurity.

85. Balt. Cnty. v. Archway Motors Inc., 370 A.2d 113, 117-18 (Md. Ct. Spec. App. 1977), discussed infra Part I.B.3.

86. Of the twenty-eight cases, nine use the expression "account stated" in some other sense. Four cases involve consumers, and each mentions only that account stated was pled in the original complaint. Champion v. United Va. Bank, 589 A.2d 1328, 1328 (Md. Ct. Spec. App. 1991) (involving an appeal by a pro se consumer debt against a judgment for a credit card debt); Edelstein v. Nationwide Mutual Insurance Co., 250 A.2d 241, 242 (Md. 1968) (involving an action between consumer and insurance company); Berwyn Fuel \& Feed Co. v. Kolb, 240 A.2d 239, 240 (Md. 1968) (involving an action for a debt for fuel oil, in which it is unclear whether the defendant was trading as a consumer or a businessman); Gillen v. Md. Nat'l Bank, 333 A.2d 329, 332 (Md. 1975) (hearing the case of a plaintiff consumer suing in relation to a withdrawal from his deposit account based on a forgery).

87. Onachuk v. Sun Ref. \& Mktg. Co., Nos. 87-2206, 87-2207, 1988 WL 132539, at *7 (6th Cir. Dec. 13, 1988) (unpublished table decision) (citing Trafton v. Youngblood, 442 P.2d 648, 653-54 
forgot about account stated. ${ }^{88}$ In the 1960 s, one New York article sought to renew interest in the cause of action. ${ }^{89}$ The real resurrection of account stated, however, took place within the past thirteen years, with over 1,900 reported cases mentioning account stated from 2000 to 2010. This rise coincides with increases in household debt and the rise of the secondary market for defaulted consumer debt. ${ }^{90}$

\section{B. The Three States of Account Stated}

One problem with the fall of account stated in the mid-twentieth century is that some of the distinctiveness of state law has been lost. Jurisprudences, sometimes even state jurisprudence, present a panAmerican view of account stated. This section will highlight some of the distinctive features of state law in three states: West Virginia, New York, and Maryland. These states contrast each other in two important respects. First, they have taken different approaches to the merchant requirement discussed above: West Virginia expressly retained it, New York expressly abandoned it, and Maryland appears not to have an authoritative decision on the issue. Second, these states have a different amount of caselaw on account stated. In New York, account stated continues its incremental development, raising questions about the implied account stated and the interaction of account stated and consumer protection statutes. In Maryland, few cases deal with account stated, and fewer still in West Virginia.

\section{West Virginia}

The only modern West Virginia treatise to mention account stated states: "[f]ailure to dispute an account rendered after the lapse of a reasonable time amounts to an admission of correctness." 91 The treatise does not mention the merchant requirement. However, West Virginia's courts explicitly declined to abandon the merchant requirement for implied

(Cal. 1968)); Keane v. McFee, 275 P.2d 960, 968 (Idaho 1954). Also more recently, for example, Credit Trust Corp. v. Richard, No. 99-CA-94, 2000 Ohio App. LEXIS 3027, at*11 (Ct. App. July 7, 2000) (quoting 1 Oh. Jur. 3d); see Target Nat'l Bank v. Samanez, No. AR07-009777, Pa. Dist. \& Cnty. Dec. LEXIS 433, at *7 (Ct. Com. Pl. Dec. 19, 2007) (noting the court's use of treatises to define account stated).

88. Rosemary E. Bucci, Account Stated Revisited, 14 SyRACUSE L. REV. 653, 653 (1962) ("[O]nly a few cases are found today in the New York reporters, and conversations with attorneys indicate that the action is unfamiliar to many of them.").

89. Id. at 659 ("The reasonably clear, simple and equitable rules of this cause of action seem to be particularly well adapted to the practice of busy attorneys today ....").

90. StRUCtURE AND PRACTICES, supra note 4, at 12-13; THE LEgAl Aid Society, supra note 1 , at 4 . Note however that it also coincides with increasing digitization of court reporting, which may be responsible for part of the increase.

91. StePhen P. Meyer, TRial HANDBoOK FOR WeSt Virginia LAWYers $§ ~ 28: 7$ (2012). 
account stated during the expansion period. McGraw v. Traders National Bank concerned the implication of an account stated between bankers and customers. ${ }^{92}$ The court said:

It is not pretended that the items in this account were gone over and a balance struck and agreed so as to bring the case within the rule of this authority; but it is claimed by the bank that, having rendered the plaintiff the account, by retaining it without objection for so long a time, it became an account stated. This seems to be the rule in Virginia and West Virginia, as between merchant and merchant, and principal and agent, with mutual accounts. But we do not think the rule applicable, as a general proposition, to transactions between banker and customer. ${ }^{93}$

Unlike the courts in Haeker and Shepard discussed above, ${ }^{94}$ the McGraw court thought that the merchant requirement related to the implication of assent, not any account stated at all. ${ }^{95}$ Mc Graw was followed by Price Hill Colliery Co. v. Pinkney in 1924 and has not been overturned. ${ }^{96}$

Neither case was a straightforward consumer collection action. McGraw was an action by a customer against a bank to recover $\$ 1,000$ that the customer had paid but did not owe. ${ }^{97}$ That sum apparently related to a bribe that the customer had proposed to the bank, so that he would be appointed receiver of a company in debt to the bank. ${ }^{98}$ The bank subsequently went into receivership and the customer sued to recover the $\$ 1,000 .{ }^{99}$ The bank objected that the matter was a settled account that could not be reopened. ${ }^{100}$ In order to become a "settled account," the debt first had to be an account stated. ${ }^{101}$ The court further doubted that the customer had retained the account rendered without objection. ${ }^{102}$ These factors do not affect the central reasoning for the retention of the merchant requirement quoted above: that assuming an actual reconciliation of accounts between consumer and business would be to "pretend." Having decided that it would not imply an account stated based on retention, the court found that it could

92. McGraw v. Traders Nat. Bank, 63 S.E. 398, 399 (W. Va. 1908).

93. Id. at 400 (citations omitted).

94. See supra notes 73-79 and accompanying text.

95. McGraw, 64 S.E. at 400.

96. Price Hill Colliery Co. v Pinkney, 122 S.E. 434, 436 (W. Va. 1924).

97. McGraw, 63 S.E. at 400.

98. Id.

99. Id. at 401 .

100. Id. at 400 .

101. Id.

102. Id. at 401 ("We do not think, therefore, from these facts and other evidence in the case, that the plaintiff can be said to have agreed to or acquiesced in the charge."). 
not infer assent from the circumstances outside the implied account stated rule. ${ }^{103}$

Pinkney involved a dispute between an employer and employee. ${ }^{104}$ The employee sued to recover unpaid benefits, and the employer defended on the grounds that the amounts due to the employee were contained in periodic account statements. ${ }^{105}$ The employer relied on the statements as a rendition of account, retained without objection, from which an account stated should be implied. ${ }^{106}$ An account stated would fix the amount owing and bar the employee's claim. Pinkney upholds the McGraw ruling in plain terms, rejecting the implication of an account stated outside the merchantmerchant or principal-agent relationship. ${ }^{107}$ Pinkney distinguished cases referred to by the employer and stated "[n]one of these cases are in conflict with the rule laid down in McGraw v. Bank."

Although their facts differ from modern collection actions, McGraw and Pinkney clearly enunciate a limitation on implied account stated. The cases upheld the merchant requirement with a limited extension to principal-agent relationships, and excluded - expressly in McGraw-banks and their customers and-implicitly in Pinkney-employers and employees. These cases do not oust account stated from consumer or employment cases entirely; they only exclude implied account stated based on rendition of an account and retention without objection. These cases would not exclude an account stated based on express assent or on real assent inferred from the surrounding circumstances.

Despite the rule in McGraw, the sparsity of caselaw in West Virginia relating to account stated, ${ }^{109}$ and the lack of any later decision abrogating McGraw, the resurrection of account stated has also taken place in West Virginia. At least two cases since 2007 have pled account stated in

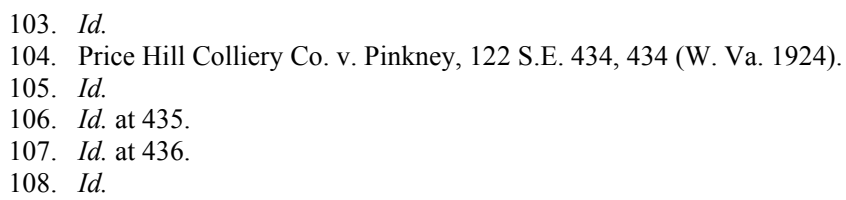

109. Only five cases since 1950 have mentioned account stated in West Virginia: Vorholt v. One Valley Bank, 498 S.E.2d 241, 245-46 (W. Va. 1997) (mentioning account stated in relation to limitation dates); Greer Limestone Co. v. Nestor, 332 S.E.2d 589, 593-94 (W. Va. 1985) (discussing account stated in relation to limitation dates; apparently this case involved business dealings); Bluefield Supply Co. v. Frankel's Appliances, Inc., 142 S.E.2d 898, 898 (W. Va. 1965) (featuring account stated in the pleadings without further mention); Preston Cnty. Coke Co. v. Preston Cnty. Light \& Power Co., 119 S.E.2d 420, 431 (W. Va. 1961) (discussing account stated in relation to statute of limitations, but specifically avoiding substantial discussion of account stated itself because "such discussion would be immaterial, since, if even they are stated accounts, they do not defeat the statute of limitations [because they are not acknowledgments in writing].”); Wright v. Standard Ultramarine \& Color Co., 90 S.E.2d 459, 464 (W. Va. 1955) (mentioning account stated in a discussion of pleading). 
consumer collection complaints. ${ }^{110}$ Both appear to have been successful. ${ }^{111}$ Because trial level collection complaints are not usually found on electronic databases, there are likely to be many similar cases. Account stated has been resurrected, at least partially, in West Virginia even though its use in consumer actions is impermissible under McGraw and Pinkney.

Of the three jurisdictions examined here, West Virginia has the least modern caselaw. Its cases relate almost exclusively to the effect of an account stated upon the statute of limitations. ${ }^{112}$ Extended discussion of the nature of account stated in West Virginia is therefore not useful or possible here. The West Virginia courts have some latitude to rely on the jurisprudence of other states, works of reference, and the old cases. ${ }^{113}$ While they may one day overturn McGraw and Pinkney, the law in West Virginia seems clear until they do.

\section{New York}

The experience of New York has been markedly different from that of West Virginia. Some of the cases often cited in support of the expansion of account stated are New York cases of the late nineteenth century. ${ }^{114}$ Rosemary Bucci's 1962 article, Account Stated Revisited, ${ }^{115}$ appeared in a New York law review and drew primarily on New York caselaw. Bucci thought it odd that account stated was not commonly used to collect unpaid accounts, given that "[t]he advantages of this action which made it popular under the law merchant in England do not seem to be any less desirable today." "116

It is unsurprising that the resurrection of account stated is strong in New York given Bucci's encouragement and the continued appearance of

110. Complaint at 1, Cach, LLC v. Wagner, No. 07-C-2177, 2007 WL 5964644 (W. Va. Cir. Ct. Oct. 12, 2007); Complaint at 1, Cach, LLC v. Anthony, No. 07-C-2309, 2007 WL 5964653 (W. Va. Cir. Ct. Oct. 25, 2007).

111. See Cach, LLC v. Wagner, No. 07-C-2177, 2008 WL 5506590 (W. Va. Cir. Ct. Jan. 10, 2008) (granting plaintiff's motion for summary judgment although it is unclear how fully this case was argued); see also, Cach, LLC. v. Anthony, No. 07-C-2309, 2008 WL 5506596 (W. Va. Cir. Ct. Jan. 7, 2008) (granting Plaintiff default judgment).

112. See cases cited supra note 110 .

113. For example, in Greer Limestone the court finds support for the proposition that "[i]n the case of an account stated, the statute of limitations runs from the date it was stated" in cases from Arkansas, Colorado and New York as well as American Jurisprudence and Corpus Juris Secundum. Greer Limestone, 332 S.E.2d at 593. See generally Hoover-Dimeling Lumber Co. v. Neill, 87 S.E. 855 (W. Va. 1916) (noting the lack of relevant in-state caselaw precedent cited by the court).

114. E.g., Stenton v. Jerome, 54 N.Y. 480, 484-85 (1873); Rodkinson v. Haecker, 162 N.E. 493, 495-96 (N.Y. 1928).

115. See Bucci, supra note 88, at 653-59 ("[Account stated] has been long recognized and sanctioned by the New York courts....”); see also supra note 90 and accompanying text (quoting Bucci's view of account stated as a favorable doctrine).

116. Bucci, supra note 88. 
account stated in New York courts. ${ }^{117}$ Since 2000, New York has seen a number of reported consumer collection actions using the account stated theory. The courts of New York have endorsed the use of account stated in collection actions. ${ }^{118}$ These developments have maintained account stated as a living area of law, which continues to develop through the work of New York appellate courts. ${ }^{119}$ These decisions are a mixed bag for consumers: some are adverse, not just to the individual debtors involved, but to the protection of consumers more widely. ${ }^{120}$ New York has accepted the evidence-reducing function of implied account stated and elevated it to the raison d'etre of account stated as a whole. ${ }^{121}$

\section{i. Outline of Account Stated in New York}

New York courts construe account stated as "an agreement between parties to an account based upon prior transactions between them with respect to the correctness of the account items and balance due." ${ }^{22} \mathrm{New}$ York also accepts the doctrine of retention without objection, and through this implied account stated the Plaintiff's burden of proof can be reduced. ${ }^{123}$ If a plaintiff can demonstrate retention without objection for an "unreasonable" period of an account statement, the plaintiff has a prima facie case on an account stated theory. ${ }^{124}$ As noted above, the merchant requirement has been expressly abandoned in New York. ${ }^{125}$

New York caselaw addressing the "reasonable period" is sparse. Most cases simply give a conclusory statement: the Plaintiff either has or has not

117. Account stated cases continued to appear in New York's reporters more frequently than those of West Viriginia or Maryland. E.g., Gurney, Becker \& Bourne, Inc. v. Benderson Dev. Co., 394 N.E.2d 282, 282 (N.Y. 1979); Galbreath-Ruffin Corp. v. 40th \& 3d Corp., 227 N.E.2d 30, 32 (N.Y. 1967); Tantillo v. Giglio, 549 N.Y.S.2d 432, 432-33 (App. Div. 1989).

118. Citibank (S.D.) N.A. v. Jones, 706 N.Y.S.2d 301, 303 (Nassau Cnty. Dist. Ct. 2000).

119. For example, New York has developed doctrine as to the application of the statute of limitations to account stated: "The statute of limitations on an action for account stated is six years ... [ $\mathrm{t}]$ he cause of action accrues at the time of the last transaction on the account." Velocity Invs. LLC v. McCaffrey, 921 N.Y.S.2d 799, 804 (Nassau Cnty. Dist. Ct. 2011) (citing Erdheim v. Gelfman, 757 N.Y.S.2d 320, 322 (App. Div. 2003)); Hertzberg \& Sanchez, P.C. v. Friendship Dairies Inc., 14 Misc. 3d 136(A) (N.Y. App. Term 2007); 75 N.Y. JUR. 2D Limitations and Laches $§ 90$ (2013) (providing that the cause of action does not accrue on an entire contract until the "completion or substantial completion of the services, or the last services were rendered").

120. Citibank (S.D.) N.A. v. Poynton, 723 N.Y.S.2d 327, 329 (App. Term 2000), discussed infra.

121. Jones, 706 N.Y.S.2d at 302.

122. Citibank (S.D.), N.A. v. Brown-Serulovic, 948 N.Y.S.2d 331, 332 (App. Div. 2012) (quoting Am. Express Centurion Bank v. Cutler, 916 N.Y.S.2d 622, 622 (App. Div. 2011)).

123. Discover Bank v. Sura, No. CV-11-3421, 2012 WL 1450028, at*3 (Poughkeepsie City Ct. Apr.26, 2012) ("Plaintiff does not have to submit a signed copy of an agreement in order to prevail on a motion for summary judgment based upon the account stated ....").

124. Id. (citing Discover Bank v. Williamson, 14 Misc. 3d 136A (N.Y. App. Div. 2007)).

125. See supra Part I.B. 
shown retention without objection within a reasonable period. ${ }^{126}$ This is to be expected for two reasons: first, New York doctrine makes the period a matter of fact rather than of law. ${ }^{127}$ Second, consumers facing collection actions rarely defend them. ${ }^{128}$ It is correspondingly unlikely that a consumer will object to a statement of account at any stage.

Evidence of periodic rendering of account stated is one area of the doctrine in which the New York courts appear to have increased the proof requirements. This requirement is not explicitly expressed, but appears from the language of courts addressing the required standards of proof: "Defendants also claim [the bank] did not render monthly statements to Defendants and thus cannot maintain a claim for account stated." 129 The courts seem to consider the failure to render monthly statements a reasonable defense.

\section{ii. A New Rule of Implication?—Part Payment}

Part payment has a role in several areas of debt collection law, particularly the tolling of the statute of limitations by acknowledgment of the debt ${ }^{130}$ and the doctrine of accord and satisfaction. ${ }^{131}$ However, part payment was not an element of the traditional formula for the inference of account stated, which spoke only of retention without objection.

126. E.g., Am. Express Centurion Bank v. Gabay, 94 A.D.3d 795, 795 (N.Y. App. Div. 2012); Scheichet \& Davis, P.C. v. Nohavicka, 939 N.Y.S.2d 848, 849 (App. Div. 2012); Am. Express Centurion Bank v. Williams, 807 N.Y.S.2d 612, 613 (App. Div. 2005); Providian Nat'l Bank v. Forrester, 716 N.Y.S.2d 112, 114 (App. Div. 2000); Discover Bank v. Robinson, 24 Misc. 3d 126, 126 (N.Y. App. Div. 2009).

127. Yannelli, Zevin \& Civardi v. Sakol, 749 N.Y.S.2d 270, 271 (App. Div. 2002) ("Whether a bill has been held without objection for a period of time sufficient to give rise to an inference of assent, in light of all the circumstances presented, is ordinarily a question of fact, and becomes a question of law only in those cases where only one inference is rationally possible.") (quoting Legum v. Ruthen, 621 N.Y.S.2d 649, 651 (App. Div. 1995)).

128. See Spector, supra note 24 (concluding that only $20 \%$ of consumers attempted to respond to lawsuits).

129. Wells Fargo Bank, N.A. v. Economical Realty, LLC, No. 25597/08, 2010 N.Y. Misc. LEXIS 4035, at*6 (Sup. Ct. July 29, 2010).

130. See generally Jay M. Zitter, Necessity and Sufficiency, in Order to Toll Statute of Limitations as to Debt, of Statement of Amount of Debt in Acknowledgment or New Promise to Pay, 21 A.L.R.4th 1121 (1983) (annotating cases that interpret the statute of limitations on a debt in light of an acknowledgement of that debt); C.C. Marvel, Part Payment or Promise to Pay Judgment as Affecting the Running of Statute of Limitations, 45 A.L.R.2d 967, 974 (1956). Many state codes expressly provide that acknowledgment tolls the statute of limitations. E.g., CAL. CIV. Proc. CODE $\S 360$ (West 2012).

131. See Vitauts M. Gulbis, Modern Status of Rule that Acceptance of Check Purporting to be Final Settlement of Disputed Amount Constitutes Accord and Satisfaction, 42 A.L.R.4th 12, 65 (1985) (discussing a series of cases in which a check that was explicitly tendered as full payment constituted accord and satisfaction, even though the creditors attempted to accept the tender only as partial payment). 
In New York, part payment is now evidence from which an inference of assent can-but need not-be drawn. ${ }^{132}$ The first signs of this development are found in Lockwood v. Thorne in $1854 .^{133}$ The Lockwood court explained its rationale clearly: the payment of the balance amounted to assent. ${ }^{134}$ In that case the debtor paid the exact sum demanded. ${ }^{135}$ Courts now sometimes find part payment as a justification or partial justification of an inference of account stated. ${ }^{136}$ Caselaw is unclear as to whether the part payment must be substantial. Citibank (South Dakota) N.A. v. BrownSerulovic concerned disputed charges on a credit card. The plaintiff failed to establish retention without objection, but also submitted as evidence checks received in part payment of the debt from which the court could infer assent. ${ }^{137}$ The court found only one check relevant and said "the sum of $\$ 300$, only reflected a small proportion of the debt owed at the time, approximately $\$ 19,000$, and by itself, did not create an inference of assent." ${ }^{138}$ Courts have found sums less than the whole amount of the debt sufficient to imply an account stated in other contexts, as in GalbreathRuffin Corp. v. 40th \& 3rd Corp. ${ }^{139}$ Like the issue of the "reasonable period," the inference from part payment continues to be treated more as an issue of fact than of law. ${ }^{140}$ Despite this, the inference from part payment is very different from the implication from rendition and retention without objection, which is a matter of course. ${ }^{141}$ The significance of inference from part payment for the theoretical foundations of account stated is discussed in Part I.C below.

132. Id. at 68; Am. Express Centurion Bank v. Cutler, 916 N.Y.S.2d 622, 623 (App. Div. 2011) ("An agreement may be implied where a defendant retains bills without objecting to them within a reasonable period of time, or makes partial payment on the account.") (emphasis added)); see also Galbreath-Ruffin Corp. v. 40th \& 3d Corp., 227 N.E.2d 30, 36 (N.Y. 1967) (inferring intent form partial payment).

133. Lockwood v. Thorne, 11 N.Y. 170, 175 (1854).

134. Id. at 175 ("Here is then affirmative and I think conclusive evidence that . . the plaintiffs agreed to it as a stated account, by drawing for and receiving the precise balance admitted.").

135. Account stated was raised not to collect a debt but in an attempt to forestall the plaintiff's attempts to challenge the correctness of the amount paid.

136. E.g., Discover Bank v. Williamson, No. 2006-1007, 2007 N.Y. Misc. LEXIS 337 (App. Div. Feb. 2, 2007); Citibank (S.D.) N.A. v. Goldberg, No. 2007-1953, 2009 N.Y. Misc. LEXIS 2086, at *3 (App. Div. Aug. 10, 2009); Cutler, 916 N.Y.S.2d at 623 (2011).

137. Citibank (S.D.), N.A. v. Brown-Serulovic, 948 N.Y.S.2d 331, 332 (App. Div. 2012).

138. Id.

139. Galbreath-Ruffin Corp. v. 40th \& 3d Corp., 227 N.E.2d 30, 36 (N.Y. 1967) ("Defendants have paid substantial amounts on account of each claim for overriding commissions, and are thereby precluded at this late date from contending that no overriding commissions became payable ....").

140. See id. (referring to partial payments as "evidentiary facts").

141. ReSTATEMENT (SECOND) OF CONTRACTS § 282 (1979) ("Retention without objection for an unreasonably long time . . . is a manifestation of assent."). 


\section{iii. The Independence of Account Stated and Consumer Protection Law}

As noted above, an action based on account stated is treated as distinct from an action for breach of contract, which gave rise to the underlying debt. Account stated may succeed where breach of contract fails. Account stated is, however, tied to the underlying debt and cannot succeed where there is no debt. How far account stated may be separated from the underlying source of the debt is important because account stated may be used to circumvent consumer protection measures. Trial courts in New York have addressed this problem in two cases and have reached conflicting conclusions.

Citibank (South Dakota) N.A. v. Poynton is a short judgment. ${ }^{142}$ It rejected oppositions to motions for summary judgment based upon two statutory consumer protection provisions: 15 U.S.C. $\S 1643(\mathrm{~b})^{143}$ (Federal Truth in Lending Act provision) and New York General Business Law section 517. ${ }^{144}$ The court explains that account stated is an independent cause of action, and neither an "action by a card issuer to enforce liability for the use of the credit card" under the Federal Truth in Lending Act nor a contractual provision caught under the New York law. ${ }^{145}$ In support of this proposition, Poynton cites W.R. Haughton Training Stables, Inc. v. Mariam Farms, Inc., and Werner v. Nelkin. Werner is a very short affirming judgment that makes no statement of law. ${ }^{146}$ Haughton simply states that "[a]n account stated constitutes in effect a separate agreement between the parties that the debt is valid and due." ${ }^{147}$ Poynton represents an extreme case of separation, in which account stated is not "an action ... to enforce liability for the use of the credit card" even though the underlying debt is a credit card debt, and its enforcement is the practical goal of the action. ${ }^{148}$ Poynton supports the proposition that creditors can circumvent consumer protection laws by suing on an account stated theory, rather than a breach of contract theory. ${ }^{149}$

At the same time as Poynton, the relationship between account stated and consumer protection statutes was examined elsewhere in New York, in

142. Citibank (S.D.) N.A. v. Poynton, 723 N.Y.S.2d 327 (App. Term 2000).

143. Stating that the burden of proof in any action by a card issuer to enforce liability for the use of a credit card is upon the card issuer to show that the use was authorized.

144. N.Y. GEN. BUS. LAW $\S 517$ (McKinney 1977) ("No agreement between the issuer and the holder shall contain any provision that a statement sent by the issuer to the holder shall be deemed correct unless objected to within a specified period of time. Any such provision is against public policy and shall be of no force or effect.").

145. Poynton, 723 N.Y.S.2d 327, 328 (App. Term 2000).

146. Werner v. Nelkin, 614 N.Y.S.2d 66, 66 (App. Div. 1994).

147. W.R. Haughton Training Stables, Inc. v. Miriam Farms, Inc., 499 N.Y.S.2d 792, 793 (App. Div. 1986).

148. Poynton, 723 N.Y.S.2d at 328

149. Id. 
Citibank (South Dakota) N.A. v. Jones. ${ }^{150}$ The provisions at issue in Jones were the same New York business law considered in Poynton, 15 U.S.C. $\S 1692 \mathrm{~g}(\mathrm{c})$, and a federal Fair Debt Collection Practices Act (FDCPA) provision prohibiting an inference of liability from a consumer's silence when sent a demand for payment by a debt collector. ${ }^{151}$ Jones held that the New York law's function was to prohibit businesses from specifying the "reasonable time" after receipt of a statement that would establish an account stated. ${ }^{152}$ Regarding the FDCPA provision, Jones held that it did not apply to original creditors such as the plaintiff. ${ }^{153}$ As a result, a statement of account from an original creditor can give rise to an account stated, while a statement of account from a debt collector cannot. ${ }^{154}$ Jones reaches the same result as Poynton, without relying on the independence of account stated. ${ }^{155}$

Surprisingly, neither case appears to have considered Bank of New York-Delaware v. Santarelli, which dealt with the same issues as Poynton but held the opposite. ${ }^{156}$ The court held that "it is evident that regardless of the technical label placed upon it, it is in fact an 'action by a card issuer to enforce liability for the use of a credit card" within the meaning of 15 U.S.C. $\S 1643(b){ }^{157}$ The court also found that the intent of both that provision and the New York law was "to thrust the burden upon the card issuer to demonstrate the full basis of its cardholder's liability, and not to allow it to hide behind pleadings couched in generalities and framed in terms of technical common law forms of action." ${ }^{158}$ Parsons v. Batchelor ${ }^{159}$ similarly held against the Poynton logic, stating:

The account stated can only determine the amount of the debt where a liability exists, and will not be permitted ... to create a liability where none existed before. Merely changing the form of

150. Citibank (S.D.) N.A. v. Jones, 706 N.Y.S.2d 301, 302 (Nassau Cnty. Dist. Ct. 2000) (quoting 15 U.S.C. $\S 1692 \mathrm{~g}(\mathrm{c})(2012)$ ).

151. Id. at 302 .

152. $I d$.

153. Id. at 303 (citing Missionary Sisters of the Sacred Heart, Inc. v. Dowling, 703 N.Y.S.2d 362 (Civ. Ct. 1999)).

154. Id.

155. See id. (finding an account stated without addressing the independence of accounts stated); see also Citibank (S.D.) N.A. v. Poynton, 723 N.Y.S.2d 327, 328 (App. Term 2000) (citing the court's reliance on the independence of account stated).

156. See Bank of N.Y.-Del. v. Santarelli, 491 N.Y.S.2d 980, 981 (Greene Cnty. Ct. 1985) (noting that plaintiff's claim is "an action by a card issuer to enforce liability for the use of a credit card" as defined under the Federal Truth in Lending Act (internal quotation marks omitted)).

157. $I d$.

158. Id. at 982 .

159. Parsons v. Batchelor, 253 N.Y.S. 728, 730 (App. Div. 1931). 
the action to evade the bar of the statute creates no new liability. ${ }^{160}$

The logic of Poynton presents a clear threat to consumer protection. Its threat lies in treating account stated as an entirely separate basis upon which to hold the defendant consumer liable. By calling account stated a "separate cause of action," the court allows itself and the plaintiff to ignore the real source of liability, which in this case is the use of the credit card. ${ }^{161}$ Whether the plaintiff chooses a breach of contract theory or an account stated theory, he is still suing for the payment of a credit card debt, which is ultimately what consumer protection laws seek to address, as held in Santarelli. ${ }^{162}$ If account stated is interpreted as an entirely separate cause of action, which is itself a source of liability, then any statutory protection directed towards the underlying contract can be circumvented.

The Jones court reasoned differently, basing its decision on a narrow reading of the purpose of the statutes rather than on the unique identity of the action for account stated. ${ }^{163}$ Jones preserves account stated in cases where (1) the consumer expressly agrees and promises to pay the amount of the debt, or (2) the plaintiff is the original creditor. ${ }^{164}$ Only debt buyers who rely upon a debt collection letter as a rendition of account would be barred by the FDCPA provision, as interpreted by Jones. ${ }^{165}$ Whether the plaintiff is the original creditor, Jones protects the "reasonable period" test for retention without objection from contractual alternation by a creditors' standard form contract, on the ground that it is the specification of a period which is prohibited under the New York General Business Law. ${ }^{166}$

Jones does not address part payment, the alternative source for implied account stated in New York as discussed above. Part payment would not be caught by the FDCPA prohibition discussed in Jones, because it does not draw an inference from silence. ${ }^{167}$

The Jones decision is most likely to be followed in jurisdictions which are protective of old common law rules. ${ }^{168}$ The Poynton decision has not attracted much attention, and, of the two, is the most objectionable. Jones is

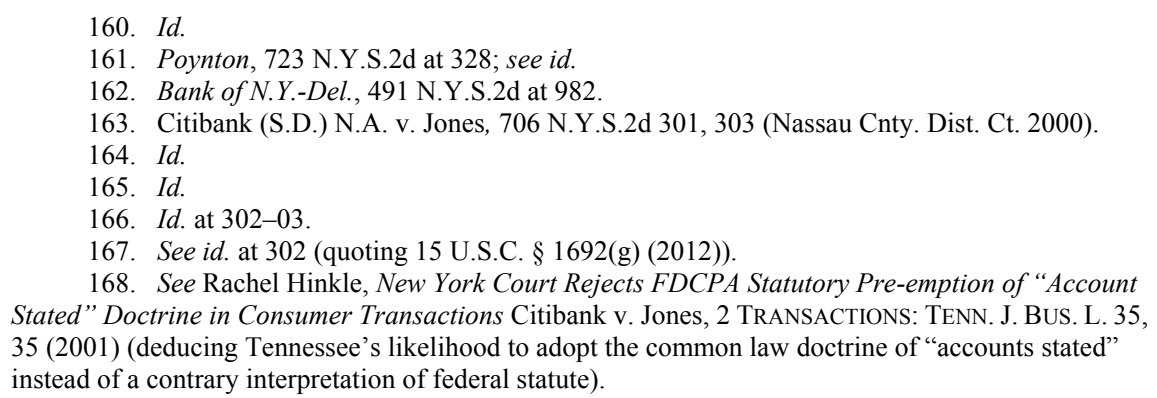


problematic because of its statutory interpretation, not because of its explanation of account stated.

The independence of account stated has one positive effect: the separation of account stated from the underlying contract prevents reliance upon contract terms - in the absence of proof of the contract. Claims for contractual interest or attorneys' fees are problematic under an account stated theory because account stated is "independent of any contract provision."169 This is so, even without taking the independence of account stated to the extreme of Poynton. Indeed, plaintiffs relying on account stated will face practical difficulties in reaching contractual interest and attorneys' fees. The additional evidence needed to show a contractual entitlement to either would be just the proof the plaintiff avoids by relying on account stated.

\section{iv. Conclusions on Account Stated in New York}

Account stated is alive and well in New York. It continues to develop in its role as a collection tool utilized by creditors to reduce the evidentiary burden they bear. Some of this development may be positive and may ultimately improve the doctrine. The rules governing the implication of account stated have continued to expand in ways which take account stated away from its narrower origins; in particular, the development that account stated can be implied from part payment. The uncertainty expressed in some of these cases demonstrates a fresh reflection on the circumstances in which account stated ought to be inferred. These issues will be further explored below in Part II.B and Part III.

New York has also seen a less positive change. The "separate cause of action" approach of Poynton represents a threat to statutory regimes that seek to regulate collection actions and, if more widely accepted, could lead to the use of account stated to enforce contracts which are themselves flawed or illegal.

\section{Maryland}

Maryland's appellate courts have rarely addressed account stated, following the wider pattern of mid-twentieth century decline. However, there is some indication that account stated continued in use through attorneys specializing in debt collection; a 1983 bar journal article, Confessions of a Collections Lawyer, indicates that account stated was in

169. Citibank (S.D.) N.A. v. Martin, 807 N.Y.S.2d 284, 293 (N.Y. Cnty. Civ. Ct. 2005) (citing Citibank S.D., N.A. v. Caputo, 8 Misc. 3d 131(A) (N.Y. App. Term 2005)). 
use and particularly associated with credit card collection actions. ${ }^{170}$ If account stated remained alive in the district courts, it rarely attracted attention in reported cases.

Maryland's experience falls in the middle ground between West Virginia and New York. Maryland has no case similar to McGrath or Pinkney. Similarly, no Maryland case removes the merchant requirement like Haeker. Whether Maryland practitioners contemporaneously accepted the trend in other states to abandon the merchant requirement will probably remain unknown, because no case of an implied account stated exists between a consumer and a business. ${ }^{171}$ While Maryland has seen more recent cases than West Virginia, each was essentially a commercial case in which account stated was a second or third cause of action. ${ }^{172}$ Those cases that discuss account stated (beyond simply noting that it was pled) elucidate the basic elements but tell us little about the circumstances in which an account stated can be implied. The three leading cases are Wathen $v$. Pearce ${ }^{173}$ Baltimore County v. Archway Motors,${ }^{174}$ and Miller v. Pyrites Co., Inc. ${ }^{175}$

The case generally identified as establishing account stated as a distinct cause of action in Maryland is Lyell v. Walbach ${ }^{176}$ The case is also the nearest that Maryland has come to a reasoned decision on an account stated between a business and a layman. Lyell concerned a debt for groceries. ${ }^{177}$ The court described account stated as an admission of a debt owing, from which a promise to pay was implied. ${ }^{178}$ It noted the contemporary practice of pleading account stated in every debt action based upon a contract, except actions against children. ${ }^{179}$ The court commented parenthetically that children cannot by law state an account. ${ }^{180}$ From these facts, the nature of

170. Cynthia B. Malament, Confessions of a Collections Lawyer, 10 LiTiG. 18, 18 (1983) ("The cause of action is usually contract or, for credit card debt, accounts stated .... The language used is straight from the hornbook.").

171. As noted above there are four consumer collection cases in the post-1950 period. However, none of those cases resulted in any discussion of account stated.

172. See Haddock, supra note 59.

173. Wathen v. Pearce, 3 A.2d 486, 491 (Md. 1939).

174. Balt. Cnty. v. Archway Motors Inc., 370 A.2d 113 (Md. Ct. Spec. App. 1977).

175. Miller v. Pyrites Co., 71 F.2d 804, 810 (4th Cir. 1934) (quoting Balt. \& O.R. Co. v. Berkeley Springs \& P.R. Co., 168 F. 770, 775 (C.C.N.D.W. Va. 1909)).

176. Lyell v. Walbach, 75 A. 339, 341 (Md. 1909).

177. Id. at 340 .

178. Id. at 341 .

179. Id.

180. Id. This rule may, in fact, be related to the merchant rule. John William Smith, in The Law of Contracts connects the inability of an infant to be bound by bills of exchange to the law merchant and the exclusion of children from the class of "merchants" and goes on to explain: "[a]gain, [the child] cannot bind himself by stating an account.... Indeed, in many instances, the statement of an account often requires so very large a share of that kind of knowledge which is derived from actual experience alone ...." SMITH 5TH, supra note 66, at 295-96. 
the debt sued, the court's acceptance of the suit, and the exclusion of children - but not others - from account stated may seem to suggest that the court in Lyell, like other courts in the same period, had abandoned the merchant requirement. ${ }^{181}$ However, Lyell is a case of an express admission of debt rather than one implied from retention without objection. ${ }^{182}$ Therefore, it did not need to confront the merchant requirement. Further, the court's reference to children being unable to state an account was clearly just an example; a second appeal in the same case reached the Court of Appeals in 1910 and was decided on the grounds that this particular defendant could not state an account under a statute. ${ }^{183}$

The 1934 case of Miller $v$. Pyrites was a complex commercial dispute heard in the federal courts, concerning the debts of a Maryland company. ${ }^{184}$ Although the court cited Baltimore \& Ohio Railroad Co. v. Berkeley Springs \& Potomac Railway Co. ${ }^{185}$ for the proposition that the assent necessary to account stated can be inferred "where no denial of it is made within a reasonable time," 186 the court found that there had been an express adjustment of accounts between the creditor and debtor. ${ }^{187}$ Indeed, because the case did not involve unliquidated damages, account stated could not have been used without an express settlement. ${ }^{188}$

Wathen v. Pearce in 1939 concerned a dispute between co-partners in a shipping business. ${ }^{189}$ The case may at first be seen as an expansion of account stated from its merchant roots, but this impression is misleading. The appellant in Wathen argued that no action could be brought at all between co-owners. ${ }^{190}$ The court found that actions for account were an exception to this rule, and drew into this exception actions for account stated. ${ }^{191}$ By this time, however, account stated had long separated from actions of account and in Maryland had been identified as a distinct common law cause of action. ${ }^{192}$ Wathen is not, therefore, an expansion case as described above. If it expands account stated at all, it is only to the case

181. Lyell, 75 A. at 341.

182. Id. (setting out the facts, including two separate admissions and promises to pay).

183. The defendant was a married woman at the time the account was alleged to have been stated. At the time, a Maryland statute voided the contracts of married women. Lyell, 77 A. at 1112.

184. Miller v. Pyrites Co., 71 F.2d 804, 805 (4th Cir. 1934).

185. Balt. \& O.R. Co. v. Berkeley Springs \& P.R. Co., 168 F. 770,775 (C.C.N.D.W. Va. 1909).

186. Miller, 71 F.2d at 810 (quoting Balt. \& O.R. Co., 168 F. at 775).

187. Id.

188. Id.

189. Wathen v. Pearce, 3 A.2d 486, 488 (Md. 1939).

190. Id. at 490 .

191. Id. (quoting Hamilton v. Conine, 28 Md. 635, 641 (1868)) (relying, in turn, upon an English statute).

192. See id. at 490-91 (holding that an account stated action may proceed against a co-owner because actions of "account shall and may be brought... by one joint tenant... against the other . . . for receiving more than comes to his just share" (quoting Hamilton, $28 \mathrm{Md}$. at 641)). 
of co-owners. Wathen is now generally cited for its rulings on the proof of trade practices, not for account stated. ${ }^{193}$

Baltimore County v. Archway is Maryland's most recent and significant appellate case on account stated. It concerned a dispute between Baltimore County and a developer, Archway Motors, about the construction of a water main that Archway requested. ${ }^{194}$ Baltimore County estimated a price and tendered the construction contract. ${ }^{195}$ After receiving bids, Baltimore County asked Archway for a contribution much greater than the original estimate, which Archway refused to pay. ${ }^{196}$ Baltimore County nevertheless built the water main and sued Archway on breach of contract and account stated theories. ${ }^{197}$ Unlike the previous cases, this case focused upon the rule of implication. ${ }^{198}$ The court construed the rule of implication, not quite as an implied agreement but an implied admission. ${ }^{199}$ Under "appropriate circumstances" the rule of implication could provide a cause of action, but in Baltimore County v. Archway the circumstances were inappropriate because there was no pre-existing liability. ${ }^{200}$ The account stated theory and the contractual theory both failed because Archway had never approved the bid. $^{201}$

Are "appropriate circumstances" in Baltimore County v. Archway limited to whether or not there is an underlying, original debt upon which the account stated is based? I argue that the court's words should not be read so narrowly. A number of factors are relevant to the implication of

193. E.g., Hirsch-Chemie Ltd. v. Johns Hopkins Univ., No. 94-2010, 1995 WL 424929, at *8 (4th Cir. July 20, 1995); Brass Metal Prods., Inc. v. E-J Enters., Inc., 984 A.2d 361, 380 (Md. Ct. Spec. App. 2008); Cook v. Sherry, 299 A.2d 811, 813 (Md. 1973) (citing Wathen to conclude that the probationary period in police department is not so definite that knowledge of it could be presumed).

194. Balt. Cnty. v. Archway Motors Inc., 370 A.2d 113, 114 (Md. Ct. Spec. App. 1977).

195. Id. at $114-15$.

196. $I d$.

197. Id. at 115 .

198. Id. at 118 .

199. Id. at $117-18$.

We agree that in order to maintain a cause of action on an account stated, all that need be shown is an admission that the stated sum of money constitutes a present existing debt. Such admission need not be express, but may be inferred. Thus under appropriate circumstances, a failure within a reasonable time to object to the correctness of a stated sum may be regarded as an admission of liability.

Id. But subsequently, the court relies upon cases which use the more common "implied agreement" or "implied assent" formulation. Id.

200. Id. at 118 ("[B]ecause the condition precedent created by $\S 25$ was not fulfilled, Archway never became liable under the agreement. Under these circumstances, an inference that Archway's failure to object within a year constituted an admission of its liability cannot be employed.”).

201. Id. 
assent (or admission) which were not at issue: the legality of the underlying debt or indeed the merchant requirement itself. ${ }^{202}$

Like other jurisdictions, Maryland has seen a flood of collection actions, in which many cases are brought by debt buyers rather than original creditors. ${ }^{203}$ Unlike most other jurisdictions, Maryland has adopted new procedural rules to ensure that collecting plaintiffs provide adequate evidence of their claims to courts and that the courts have clear guidance about the evidence they should demand from collecting plaintiffs. ${ }^{204}$ At first sight, these sensible steps by the Rules Committee may appear to trump the burden-reducing effect of the account stated doctrine. However, this is not necessarily so because the Rules Committee does not exist to reform substantive law. ${ }^{205}$ The rule change simply alters the evidence required for Maryland's equivalent of a default judgment - the affidavit judgment. ${ }^{206}$

The "independence" aspect of account stated, which gave the New York courts difficulty in Poynton, may create difficulty about the evidence required by the new rules. For example, Rule 3-306(c)(4)(D) requires "if the claim is founded upon a note, security agreement, or other instrument, the original or a photocopy of the executed instrument, or a sworn or certified copy, unless the absence thereof is explained in the affidavit." ${ }^{207}$ It could be argued that account stated is not a claim founded on any of those instruments, even if the underlying debt was. A bold creditor might even claim that an action for account stated does not relate to a consumer debt. A consumer debt is defined by Rule 3-306(a)(3) as "a secured or unsecured debt that is for money owed or alleged to be owed and arises from a consumer transaction." ${ }^{208}$ The argument being that an account stated is not a consumer transaction, but an independent cause of action and, therefore, an account stated suit should not be subject to the effects of the new rule. This

202. See Lyell v. Walbach, 77 A. 1111, 1112 (Md. 1910) (denying a claim on accounts stated against a party who was legally unable to contract for the purchase of goods); see supra notes 176-183 and accompanying text.

203. State Collection Agency Licensing Bd. \& Office of the Attorney Gen. Of Md., Amendments to THE Maryland Rules of Procedure in CONSUMER DeBt COLleCtion Cases 2 (2011), available at http://dlslibrary.state.md.us/publications/Exec/DLLR/HB358Ch332\%288\%29_ 2011.pdf.

204. MD. R. 3-306(d) (West 2013).

205. A committee note to Rule 3-306(d)(2)(B) makes clear that "[t]his Rule is procedural only, and subsection (d)(2)(B)(iii) is not intended to address the substantive issue of whether interest in any amount may be charged on a part of the charge-off balance that, under applicable and enforceable Maryland law, may be regarded as interest". While the note is directed at one specific provision, it is true of the whole rule: it is not determinative of substantive issues. MD. R. 3-306(d).

206. MD. R. 3-306(b).

207. MD. R. 3-306(c)(4)(d).

208. MD. R. 3-306(a)(3). 
argument is conceptually similar to that in Citibank v. Poynton, and just as dangerous. ${ }^{209}$

Such an argument should not be accepted because it would frustrate the purpose of the Rule 3-306 amendments, which ensure that complaints based on consumer debt are accompanied by adequate evidence. ${ }^{210}$ Because Rule 3-306 is fundamentally a rule about pleading, specifying the documentation necessary for the court to grant a judgment in default, ex parte, and because few consumers respond to debt collection suits, the burden of judging such an argument would fall upon district court judges and their clerks. In this situation there is the risk that different district courts within Maryland will reach different conclusions and, until a contested case raises the issue, there will be no authoritative resolution.

The new rules may conflict with account stated doctrine on one other point; Rule 3-306(d)(1) requires the plaintiff in some cases to provide either a writing signed by the debtor, evidencing the debt, or statement of account which shows some actual use of the account by the defendant. ${ }^{211}$ A plaintiff cannot simply provide, for example, the last credit card statement sent to the defendant, showing that they owe money, but not showing any transactions on the card. ${ }^{212}$ Normally, such a statement would be sufficient to found an account stated because generally, it would be a rendition of account. The best solution to this conflict is to say that a final statement, showing no transactions, is not sufficient evidence of the "prior transactions" element of account stated, but even this solution requires clarification of the substantive law on account stated.

The potential conflict between the procedural rules and the doctrine of account stated raises another issue: is account stated really substantive law at all? Some argue that Maryland abolished account stated with the abolition of common law pleading in $1984 .{ }^{213}$ While account stated certainly has a procedural aspect, the argument is problematic in Maryland because, as early as 1909 , account stated was regarded as a cause of action and therefore a part of substantive law. ${ }^{214}$ Pleading for "money due on an

209. See supra Part I.B.2(iii); see generally Citibank (S.D.) N.A. v. Poynton, 723 N.Y.S.2d 327 (App. Term 2000) (understanding the conceptual argument made in said case).

210. State Collection Agency Licensing BD. \& Office of the Attorney Gen. OF MD., supra note 203, at 2.

211. MD. R. 3-306(d)(1) applies to cases where a debt-buyer is the plaintiff and is seeking to collect on purchased consumer debts. MD. R. 3-306(d)(2)(A) requires a copy of the terms and conditions of the underlying contract, but an exemption is provided where the original creditor was a federally regulated financial institution. MD. R. 3-306(d)(2)(B). Since most sales of defaulted consumer debt are by such institutions, few cases are likely to be caught by Rule 3-306(d)(2)(A). See STRUCTURE AND PRACTICES, supra note 4, at 13 (the major source of debts for debt buyers is "charged-off" accountscharging off is required under federal regulations).

212. MD. R. 3-306(1).

213. See supra note 26

214. Lyell v. Walbach, 75 A. 339, 341 (Md. 1909). 
account stated" is contrary to the modern demand for fact pleading and the absence of common law formality. ${ }^{215}$ However, the underlying rule of account stated, as part of substantive law, must still exist.

\section{Problems of Account StAted in Modern CONSUMER ACtions}

In the fifty years since Bucci "revisited" account stated in New York, account stated has been resurrected nationwide. This Part will outline the resurrection of account stated and argue that the resurrection is harmful to consumers and contrary to good consumer protection policy. The implied assent in implied account stated is bad for consumers for three reasons. First, the implication does not reflect reality: a consumer's failure to dispute a bill does not equate, in the mind of the consumer or the business, to an agreement that the bill is accurate and a promise to pay it. This is simply an archaic fiction. Second, the implication does not reflect the consumer's expectation on entering into a transaction. It is not a rule or an accepted practice among consumers that ignoring a bill is the same as agreeing that it is right. Third, the implication places an unreasonable burden on consumers to determine if a bill is correct. A consumer would need mathematical and legal knowledge, not to mention time and expense, which they do not possess. Finally, particular interpretations of account stated undermine consumer protection, not only at the collection stage but potentially at the transaction stage as well. Interpretations such as that in Citibank v. Poynton, discussed above, threaten to provide creditors with an opportunity to collect on an account, despite statutory prohibitions arising because of the way in which the original transaction was conducted. ${ }^{216}$

\section{A. The Resurrection}

The widespread resurrection of account stated is hard to quantify. State court collection actions at the trial level do not usually reach legal databases such as LexisNexis; and publicly accessible state court case management systems do not usually record the causes of action pled in a complaint in a searchable form. Empirical evidence of the resurrection is therefore generally lacking. However, the resurrection can be illustrated using the number of reported cases. In the LexisNexis database, the number of cases mentioning both "account stated" and "credit card" increased from 14

215. The appropriate challenge to such a plea would therefore seem to be that the pleading is itself deficient.

216. Citibank (S.D.) N.A. v. Poynton, 723 N.Y.S.2d 327, 328 (App. Term 2000). 
between 1990 and 2000 to 250 between 2000 and $2010 .{ }^{217}$ Obviously the number of credit card collection suits generally has increased over the past ten to twenty years, as has the reach of electronic databases. I performed similar searches for quantum meruit and breach of contract cases to determine the factors causing the increase in account stated cases. These cases increased from 41 to 174 and from 644 to 2,391 respectively. While breach of contract and quantum meruit cases multiplied by about four times, account stated cases multiplied nearly eighteen times. ${ }^{218}$ While this straw poll is no substitute for hard statistics, it does seem compelling evidence that account stated is back with a vengeance, at least in cases about credit cards.

Other evidence of the resurgent use of account stated in consumer collection can be found in the statements of consumer advocates. For example, some authors have noted "many [collection actions] allege that an account stated exists",219 "[o]ften the complaint is pled as an account stated", ${ }^{220}$ "[t] he second most common cause of action pleaded and by far the most dangerous for consumers, an account stated ...."221 "[Plaintiffs] often initiate collection cases against consumers without any documentation... [i]nstead, they simply offer up an affidavit from an employee ... and/or sue on an account stated theory.",222

Both original creditors and debt buyers use implied account stated. When pled by debt buyers, it usually relies upon a rendition of account by the original creditor. Debt buyers attempting to rely upon their own renditions of account would face both the possible preemption of account stated by the federal Fair Debt Collection Practices Act, ${ }^{223}$ and difficulty in establishing a prior relationship with the consumer. Reliance on a rendition by the original creditor means that the debt-buyer will need, at least, to produce a copy of a statement sent by the original creditor. Among large

217. Searches performed $2 / 19 / 2013$. The selection of available databases means that this is effectively a straw poll of appellate or otherwise reported cases, and may not measure the prevalence of trial court decisions based upon account stated.

218. Searches performed on $2 / 19 / 2013$. The apparent increase in account stated cases reported may mirror a far greater increase in the number of trial-level debt-collection suits in which account stated is pleaded, however it would be difficult to obtain meaningful data to quantify these trial court increases. An additional variable is that the key phrases might appear in some cases which are not credit card collection actions using those particular causes of action, however, there is no reason to suppose that this weakness in the search significantly alters the conclusion; account stated has grown out of proportion with the other actions.

219. Glover, supra note 8, at 1122 .

220. Holland, supra note 21 .

221. Rooney, supra note 21.

222. Carolyn Carter, et. al., The Credit Card Market and Regulation: In Need of Repair, 10 N.C. BANKING INST. 23, 44-45 (2006).

223. See infra Part I.B.2(iii). 
debt-buyers, only $6 \%$ of accounts sold included any account statements. ${ }^{224}$ To sue on an account stated theory, as on a breach of contract theory, it is necessary to obtain evidence from the original creditor.

Some states have affirmed the resurrection. Texas, ${ }^{225}$ Connecticut, ${ }^{226}$ Massachusetts, ${ }^{27}$ Iowa, ${ }^{228}$ Florida, ${ }^{229}$ and perhaps Ohio ${ }^{230}$ courts have accepted the use of account stated in consumer collection actions. However, as with the expansion of account stated in the nineteenth century, acceptance is not uniform. Some courts have expressed doubt about the use of account stated, most notably the courts of Pennsylvania. ${ }^{231}$ Further, particular cases have rejected account stated for policy reasons. For example, in New York, matrimonial fee arbitration rules have displaced account stated in that context. ${ }^{232}$

224. StRUCTURE AND PRACTICES, supra note 4, at 35

225. Dulong v. Citibank (S.D.) N.A., 261 S.W.3d 890, 892 (Tex. App. 2008); followed by Jaramillo v. Portfolio Acquisitions, LLC., No. 14-08-00939-CV, 2010 WL 1197669, at*7 (Tex. App. Mar. 30, 2010) ("In contrast, a cause of action for an account stated is the proper tool for credit card collection.").

226. Citi Bank (S.D.) N.A. v. Filip, No. CV-096-000823S, 2010 Conn. Super. LEXIS 1757, at *16 (Conn. Super. Ct. July 12, 2010) (discussing the use of account stated in consumer collections in Connecticut).

227. Citibank (S.D.) N.A. v. DeCristoforo, No. 09-02536C, 2011 WL 1020497, at *6 (Mass. Super. Ct. Jan. 4, 2011) (finding defendant "clearly liable" under account stated theory, but denying summary judgment due to disputed facts), vacated by Citibank (S.D.) N.A. v. DeCristoforo, No. 12-P603, 83 Mass. App. Ct. 1131 (Table), at *3 (May 17, 2013).

228. Capital One Bank (USA), N.A. v. Denboer, 791 N.W.2d 264, 273-75 (Iowa Ct. App. 2010) (holding account stated appropriate for consumer collection actions).

229. Farley v. ChaseBank, U.S., N.A., 37 So.3d 936, 937-38 (Fla. Dist. Ct. App. 2010) (holding that lower evidentiary requirements apply in account stated consumer collection action).

230. See Creditrust Corp. v. Richard, No. 99-CA-94, 2000 Ohio App. LEXIS 3027, at *2 (Ct. App. July 7, 2000) (applying account stated doctrine in a consumer collection action), but see Worldwide Asset Purchasing L.L.C. v. Sandoval, No. 2007-CA-00159, 2008 WL 5104769, at *5 (Ohio Ct. App. July 14, 2008) (holding that an account stated claim required a zero starting balance).

231. See Capital One Bank (USA), N.A. v. Clevenstine, 7 Pa. D. \& C.5th 153, 157-58 (Ct. Com. Pl. 2009) (stating that an account stated theory may have been appropriate when credit card issuers gave cardholders fixed interest, but is less appropriate with the varied interest rates and fees of today); see generally Target Bank v. Samanez, 2007 Pa. Dist. \& Cnty. Dec. LEXIS 433 (Ct. Com. Pl. 2007), discussed infra.

232. Lewis \& Merritt v. Smith, 650 N.Y.S.2d 921, 923 (Sup. Ct. 1996).

$[\mathrm{T}]$ he rules have impacted upon the common law principle of an account stated where... that principle is utilized to imply agreement on billings in a matrimonial matter so as to defeat application of [the rules] ... mere silence and failure to object to the billings cannot be construed as an implied assent when it equally suggests lack of assent.

Id. (quoted in Lester Brickman, Mandatory Fee Arbitration Under New York's Matrimonial Rules, 3 CARDOZO J. CONFL. RESOL. 1 (2001), available at http://cardozojcr.com/issues/volume-3-1/article/). 


\section{B. Policy Problems of Account Stated}

Courts across the country differ on the merits of using account stated in consumer collection actions. Some courts have been unequivocal in their rejection of account stated: "[a]n account stated is more appropriately pled in a situation in which two equal, sophisticated parties have an ongoing business relationship. An account stated theory is not appropriate in a credit card account case." ${ }^{233}$ Others have taken a more nuanced approach, specifically rejecting the automatic implication of assent from silence. ${ }^{234}$ Some state courts have excluded account stated from particular types of collection action in favor of other causes of action better suited to those cases. ${ }^{235}$ Other courts have defended the use of account stated $^{236}$ against apparently conflicting state statutes ${ }^{237}$ and policy arguments. ${ }^{238}$ Still others, while supporting the principles of account stated, have imposed additional obstacles to successful pleas of account stated. ${ }^{239}$ On both sides, these decisions are generally those of trial courts or unpublished appellate opinions and thus, have a limited effect on the disposition of undefended collection actions.

To see the failings of the doctrine, we should look at it with fresh eyes. Forget, for a moment, that the doctrine has enjoyed three hundred years of approval in the courts and look at its effects. Forget, also, those rare cases in which the debtor explicitly assents and promises to pay the debt. Account

233. Clevenstine, 7 Pa. D. \& C. 5th at 157.

234. Samanez, $2007 \mathrm{~Pa}$. Dist \& Cnty. Dec. LEXIS 433, at *23; see Nelson v. First National Bank Omaha, No. A04-579, 2004 WL 2711032, at*3 (Minn. Ct. App. Nov. 30, 2004) (requiring more than the retention of billing statements "without objection").

235. Jarmillio v. Portfolio Acquisitions, LCC, No. 14-08-00939-CV, 2010 WL 1197669, at *7 (Tex. App. Mar. 30, 2010) (distinguishing actions on an account stated from actions on a sworn account).

236. Some of these cases arise from suits against debt collectors brought under the Fair Debt Collection Practices Act. See Hadsell v. Mandarich Law Group, LLP, No. 12-cv-235-L, 2013 WL 1386299, at *4 (S.D. Cal. Apr. 4, 2013) (dismissing Plaintiff's FDCPA claim and holding that account stated is an accepted cause of action in credit card collection cases in California).

237. Capital One Bank (USA), N.A. v. Denboer, 791 N.W.2d 264, 275-80 (Iowa App. 2010) (holding that section 537.5114 of the Iowa consumer credit code does not abolish account stated in consumer collection actions).

238. See Capital One Bank (USA), N.A. v. Spicer, No. 2009-774, 2009 Pa. Dist. \& Cnty. Dec. LEXIS 244, at *9 (Ct. Com. Pl. Aug. 6, 2009) (holding that policy arguments raised in Clevenstine regarding the complexity of credit card terms of agreement are essentially issues of fact and do not prevent a plea of account stated).

239. E.g., Citi Bank (S.D.) N.A. v. Filip, No. CV-09-6000823S, 2010 Conn. Super. LEXIS 1757 , at $* 5, * 7-8, * 14-16$ (Conn. Super. Ct. July 12, 2010) (holding that account stated can be used in collection actions but to provide sufficient evidence plaintiff must produce copies of each statement of account rendered to defendant); Worldwide Asset Purchasing, L.L.C. v. Sandoval, No. 2007-CA-00159, 2008 WL 5104769, at *7 (Ohio Ct. App. July 14, 2008) (Hoffman, J., dissenting); Creditrust Corp. v. Richard, No. 99-CA-94, 2000 Ohio App. LEXIS 3027, at *7-8 (Ct. App. July 7, 2000) (accepting account stated but holding that it must be possible to trace the account back to a provable sum and preferably a zero balance). 
stated assumes that, by failing to object to a bill, the consumer agrees the bill is correct and makes an enforceable promise to pay. ${ }^{240}$ In reality, however, consumers fail to dispute or reply to bills for many reasons: they may be unable to pay on time, but anticipate making payment at a later time; they may not receive the bill; they may not recognize the senderparticularly if the bill is sent by a debt buyer, or sent after a substantial interval; they may simply mislay or forget the bill; or finally, they may receive but never read the bill. None of these would lead a reasonable person to conclude that the consumer "assented" and "promised to pay" the bill. If account stated doctrine requires the courts to say that they have assented and promised to pay, then the assent and promise are legal fictions. Fictions are, as S.F.C. Milsom observed "a symptom of the deep conceptual artificiality into which logic has forced the common law." ${ }^{241}$ In Part III below, this Article will examine the conceptual problem underlying the search for a principled justification of implied account stated.

The implication of assent is a fiction, but the law relies on many such fictions, so well-known and accepted that we hardly notice them at all. ${ }^{242}$ However, the fictional circumstances implied by account stated do not match the expectations of consumers when they enter into contracts with businesses. Consumers are unaware of the doctrine and its effects. Even some information published as advice for consumers facing collection law suits does not mention account stated. ${ }^{243}$ Implied account stated is not in that category of fictions, which Lon Fuller described as "used with a complete consciousness of its falsity." "244 It is not like the untrue allegations of classical legal fictions, which were acknowledged to be false. ${ }^{245}$ The

240. Capital One Bank v. Clevenstine, 7 Pa. D. \& C. 5th 153, 157 (Ct. Com. Pl. 2009).

241. S.F.C. Milsom, Reason in the Development of the Common Law, 81 L. Q. REV. 496, 499 (1965).

242. See generally LON FUlLER, LEgAL FiCtions (1967) (explaining the concept of a legal fiction); Aviam Soifer, Reviewing Legal Fictions, 20 GA. L. REV. 871, 873 (1986) (discussing legal fictions' meaning, examples, and significance for law and letters); see Nancy J. Knauer, Legal Fictions and Juristic Truth, 23 ST. THOMAS L. REV. 1, 3 (2010).

It would be a mistake, however, to conflate the moribund common law fictions that punctuate the first-year Property course with the broader category of legal fictions. Far from being a historical oddity, legal fictions are common features of not only our common law, but also our statutory and regulatory law.

Id.

243. E.g., Richard Slottee, Debtors' Rights, OR. STATE BAR (Jan. 2012) http://www.oregonstatebar.org/public/legalinfo/1021_DebtorsRights.htm.

244. FULLER, supra note 242, at 9-10 ("A fiction becomes wholly safe only when it is used with a complete consciousness of its falsity ... it is precisely those false statement that are realized as being false that have utility.").

245. For example, the allegation that the Island of Minorca was located in London. Mostyn v. Fabrigas, (1774) 98 Eng. Rep. 1021, 1021 (K.B.). 
fiction of implied account stated assumes that everyone-including the consumer-follows the same accounting practices as early modern merchants. For consumers, implied account stated is simply a harsh, archaic technicality.

The Common Pleas in Capital One v. Clevenstine makes the last general criticism of account stated: the doctrine places an unfair burden on consumers. ${ }^{246}$ Suppose that a consumer receives a bill. If she can pay the bill all is well. If she cannot pay the bill, the consumer must object within a reasonable time, otherwise an account stated will be implied, fixing the amount of the debt as the amount billed. ${ }^{247}$ That determination can be reopened only on very limited grounds, typically fraud and mistake. ${ }^{248}$ Substantial resources are required to determine whether a modern consumer bill is error free. ${ }^{249}$ Many consumers lack the basic skills necessary to check a bill for non-obvious errors. For example, very few consumers are able to perform such basic financial operations as the comparison of the substantive terms of two credit card agreements or the calculation of interest on a mortgage. ${ }^{250}$ Further, if the consumer does detect an error in a bill, the burden is on her to articulate the problem to the business. ${ }^{251}$ These burdens are placed on consumers who are already in difficulty: they are unable to pay a bill they received. These are not burdens deliberately placed upon consumers by a legislature or through a widely known and longstanding legal rule (such as the rule that one is bound by the terms of a contract, even if one has not read them). There is no reason why these consumers should be required to detect errors in the bill any sooner than statutory limitation periods require. Equally, businesses should not be partially relieved of their evidentiary burden simply by showing that they sent a bill to the consumer and received no reply.

A more disturbing use of account stated is found in Citibank $v$. Poynton, a New York case in which the debtor raised statutory defenses to a collection suit. ${ }^{252}$ While those defenses barred a suit for breach of the original credit card contract, the court held that they did not bar an account

246. Captial One Bank v. Clevenstine, 7 Pa. D. \& C.5th 153, 158 (Ct. Com. Pl. 2009).

247. Id. at 157 ("When a debtor has had an opportunity to scrutinize the account, his or her silence is prima facie evidence of acquiescence in an account stated.").

248. Id. at 158 .

249. Id. (finding that " $[\mathrm{i}] \mathrm{t}$ is unreasonable to expect the average debtor to understand the changing terms of a customer agreement such that he or she can object to any invoice received in a timely manner").

250. Alan M. White \& Cathy L. Mansfield, Literacy and Contract, 13 STAN L. \& POL'Y REV. 233, 237 (2002).

251. Id. at 240.

252. See Citibank (S.D.) N.A. v. Poynton, 723 N.Y.S.2d 327, 328 (App. Term 2000) (asserting that the use of a statutory defense is disturbing). 
stated suit. ${ }^{253}$ By pleading account stated, the plaintiff was able to collect on a transaction for which collection was otherwise barred. ${ }^{254}$

There is no policy reason why account stated should not be subject to the same defenses as the original debt. Such a rule would seem to undermine the protections that legislatures intend to provide when they create similar defenses. Poynton should not be regarded simply as a single bad decision, but as an example of how account stated can trick courts into accepting bad arguments. Account stated seems, in its language, like novation: the parties agree to a renewal of contractual obligations. However, when assent is implied, the character of the transaction is different: it is nothing but an un-answered demand by a creditor to a debtor. The contractual associations of account stated and its "implication of assent" are, in these circumstances, merely a fiction.

The use of account stated to avoid statutory restriction is not new. Samuel Stoljar noted its use in nineteenth century cases, ${ }^{255}$ and concluded that its use most likely remained in the legitimation of semi-legal debts. ${ }^{256}$ Whether this use is something we ought to approve of in the twenty-first century is doubtful.

\section{TheORETICAL PROBLEMS OF ACCOUNT StATED}

Until recently, the rarity of account stated cases has spared it much of the theoretical scrutiny applied to other causes of action. ${ }^{257}$ The central theoretical question is whether account stated is more like a contract or a quasi-contract. It is usually called "an agreement." This statement, casting account stated as a variety of contract, is very often followed by the caveat that this "agreement" may be implied from retention without objection as described above. ${ }^{258}$ This section will argue that this "implication" is entirely

253. Id.

254. Id. at 329.

255. Stoljar, supra note 51 , at $378-81$.

256. Id. at 382 ("In one area, however, account stated has continued to have a little more importance. This is the area of illegal or rather semi-illegal contracts.") Stoljar goes on to note the mixed reception account stated has received in such uses "where the transaction was not semi-illegal but was fully illegal ... it was indeed thought that this too could possibly be an account stated. In the view of another court, however, such actions were frivolous and vexatious and just a brazen attempt to get round the Gaming Act." Id. (citing Guggenheim v. Ladbroke \& Co. Ltd., [1947] 1 All. E.R. 292 (U.K.) and Day v. William Hill, [1949] 1 All. E.R. 219 (U.K.)).

257. Few law review articles discuss account stated in any detail and those that do are often from the first half of the twentieth century or earlier. E.g., Belsheim, supra note 83 (providing analysis of account stated in 1931); Haddock, supra note 59 (providing analysis of account stated in 1886). More recent works often focus on the history of account stated. E.g., MiLsOM, supra note, 46, at 376; Stoljar, supra note 51 , at 376.

258. Haddock, supra note 59, at 78; see also, Belsheim, supra note 83, at 469-70 (providing an example and analysis of a relationship that could give rise to an action of account stated); Stoljar, supra 
fictional, at least in the case of actions between businesses and consumers. The courts do not really mean to say that they believe the consumer has formed a voluntary agreement, in which she agreed with the creditor about the amount and validity of the debt, based on retention without objection. The law requires the courts to assume that the agreement exists.

\section{A. Account Stated as an Agreement}

Traditionally, an account stated is an agreement, express or implied, to pay a pre-existing debt. ${ }^{259}$ The Restatement of Contracts adopts a slightly different formulation, but it still relies on assent. ${ }^{260}$ Most modern courts have used "agreement" language. ${ }^{261}$ Account stated is sometimes regarded as something more akin to an evidentiary presumption. ${ }^{262}$ In Illinois, account stated is described as an agreement but has the effects of an evidentiary presumption. The two explanations co-exist: the test for account stated described in agreement terms, but its effects limited to the determination of the amount of a debt. ${ }^{263}$

note 51, at 379 (explaining "settlement of accounts" in contractual terms, but later recognizing that some admissions of indebtedness are noncontractual).

259. For example, "[a]n 'account stated' is broadly defined as an agreement, based on the prior transactions between the parties to an open account." 1 AM. JUR. 2D Accounts and Accounting $\S 26$ (2005); "An account stated is an agreement that the balance and all items of an account representing the previous monetary transactions of the parties are correct, together with a promise to pay that balance." 1A C.J.S. Account Stated $\S 1$ (2005).

260. RESTATEMENT (SECOND) OF CONTRACTS § 282 (1979) (“An account stated is a manifestation of assent by debtor and creditor to a stated sum as an accurate computation of an amount due the creditor.").

261. E.g., U.S. Neurosurgical v. City of Chi., 572 F.3d 325, 333 (7th Cir. 2009) (“An account stated is an agreement between the parties ...." (quoting Dreyer Medical Clinic, S.C. v. Corral, 591 N.E.2d 111, 114 (Ill. App. Ct. 1992))); Heidtman Steel Prods. v. Faurecia Auto. Seating, Inc., 919 F. Supp. 2d 928, 932 (D. Ohio 2013) ("[A]n account stated is based on a separate agreement between the parties ...." (quoting Fisher Sand \& Gravel v. Neal A. Sweebe, Inc., 810 N.W.2d 277, 281-82 (Mich. 2011))); Petersen Bros., Inc. v. Phoenix Underground Constr., Inc., No. 1:12-cv-0936AWIDLB, 2012 WL 6020112, at *2 (E.D. Cal. 2012).

262. See, e.g., Freeland v. Heron, Lenox \& Co., 11 U.S. (Cranch) 147, 151 (1812) ("[H]is silence and acquiescence shall bind him. [A]t least so far as to cast the onus probandi on him." (emphasis added)); Nw. Motors v. James, 788 P.2d 584, 587 (Wash. Ct. App. 1990) ("Comment $c$ to $\S$ 282 [of the 2d Restatement of Contracts] suggests that an account stated does not itself result in discharge, but is used as an admission of the contents of the account for evidentiary purposes ...."); Citibank N.A. v. Hull, 26 Pa. D. \& C.5th 188, 199 (Ct. Com. Pl. 2012) (to similar effect); also, less clearly Bowman v. Tooker, 105 N.Y.S.2d 36, 37 (App. Div. 1951) ("[R]eference therein to an account stated for the year 1949 is merely an evidentiary allegation, not the statement of another cause of action." (emphasis added)).

263. Patrick Eng'g Inc. v. City of Naperville, 976 N.E.2d 318, 336 (Ill. 2012) (“[A]n account stated is "merely a final determination of the amount of an existing debt." (quoting Motive Parts Co. of Am., Inc. v. Robinson, 369 N.E.2d 119, 124 (Ill. App. Ct. 1977))); D.S.A. Fin. Corp. v. Cnty. of Cook, 801 N.E.2d 1075, 1080 (Ill. App. Ct. 2003); see Dreyer Medical Clinic, S.C. v. Corral, 591 N.E.2d 111, 114 (Ill. App. Ct. 1992) (“[A]n account stated is an agreement between parties who previously engaged in transactions," but "it merely determines the amount of the debt where liability previously existed."). 
The evidentiary view is understandable given the dependence of account stated on a pre-existing debt and the possibility of re-opening an account on grounds of mistake or fraud. However, even courts that adopt this view rely on the same underlying elements for the existence of an account stated, and those elements still involve at least the allegation of an agreement about the amount owed. ${ }^{264}$

The "agreement" explanation therefore is the favored rationale for account stated. However, at least one author found the account stated "agreements" theory problematic because it violates the silent acceptance rule discussed below. ${ }^{265}$ Because the rule against silent acceptance is a contractual rule, ${ }^{266}$ it is necessary to consider the relationship between account stated and contracts before pressing the silent acceptance argument.

Describing account stated as an agreement presents some doctrinal confusion. Even express account stated, which depends on an agreement, is not quite the same as a contract because express account stated is more limited in scope. Account stated requires some prior debt. ${ }^{267}$ Its subject matter is limited and inflexible: account stated can only relate to the payment of a specified sum of money. ${ }^{268}$ There is even some difficulty in determining the consideration involved in account stated: it is usually said that the stating of the account is the consideration. ${ }^{269}$ These limitations should not immunize account stated from the ordinary principles of contract law. If account stated is to be discussed and justified as an agreement, then it should conform to basic principles about the meaning of "agreement." In the next Part, I will focus on the most problematic inconsistency between implied account stated doctrine as it has been recently applied, and the general principle that contractual offers cannot be accepted by silence.

264. Brobst v. Johnson Realty Group, Ltd., No. 1-11-0991, 2012 IL App. (1st) 110991-U, at *4 (Ill. App. Ct. Aug. 28, 2012); Dreyer Medical Clinic, S.C, 591 N.E.2d at 114; See also Motive Parts Co. of Am., Inc., 369 N.E.2d at 122 ("The agreement mentioned in these definitions must, of course, manifest the mutual assent of the debtor and creditor." (citing Canadian Ace Brewing Co. v. Swiftsure Beer Co., 149 N.E.2d 442, 446 (Ill. App. Ct. 1958))); Patrick Eng'g Inc., 976 N.E.2d at 336-37 (requiring uniformity in the "amounts actually billed" and the "amounts allegedly billed" to establish a correct statement of account).

265. A.L.C., When Silence Gives Consent, 29 YALE L.J. 441, 444 (1920).

266. See RESTATEMENT (SECOND) OF CONTRACTS $\S 69$ (1979) (stating that silence in response to an offer is generally not acceptance).

267. 1A C.J.S. Account Stated $\S 5$ at 65 (2005).

268. Id., at 62 .

269. See BAKER, supra note 52. 


\section{B. Account Stated as a Violation of the Silent Acceptance Rule}

A well-known rule of contract law is that a contract cannot be accepted by silence. ${ }^{270}$ This rule is embodied in the Restatement (Second) of Contracts section 69, which provides three exceptions to the rule that silence cannot generally constitute a contractual acceptance. The exceptions are: (1) where the offeree both takes offered services and has reason to know that they were offered with the expectation of compensation; (2) where the offeror tells the offeree that assent can be given by silence, and the offeree is silent with the intention to accept the offer; and (3) where it is reasonable that the offeree should notify the offeror if he does not intend to accept, particularly in the case where a trade usage or course of dealing gives the offeror the understanding that silence will constitute acceptance. ${ }^{271}$ The rule against silent acceptance is also found in internationally accepted statements of contract law. ${ }^{272}$ The Restatement (Second) of Contracts does not reconcile the silent acceptance rule with account stated. ${ }^{273}$

When it comes to account stated, silent acceptance is permitted. Looking back to its origins, we can see that the rule once filled a space within one of our modern exceptions: account stated arose from trade practices of international merchants. ${ }^{274}$ International merchants accepted that receiving an account by post created a duty either to object or assent to the account received. ${ }^{275}$ For merchants, silence inferred an assent because it was understood in their community that it was assent. ${ }^{276}$ rule).

270. See ReStatement (SECOND) OF CONTRACTS $§ 69$ (1979) (stating the exceptions to the

271. Id., at cmt. (d).

272. Comm'n on Int'l Trade Law, U.N. Convention on Contracts for the International Sale of Goods, at 6, U.N. Sales No. E.10.V.14 (2010) art. 18(1) ("Silence or inactivity does not in itself amount to acceptance."). See also INT'L INST. FOR THE UNIFICATION OF PRIVATE LAW, UNIDROIT PRINCIPLES OF INTERNATIONAL COMMERCIAL CONTRACTS 43-45 (3d ed. 2010) ("[A]s a rule mere silence or inactivity on the part of the offeree does not allow the inference that the offeree assents to the offer.").

273. Implied account stated is described by the Restatement as a "manifestation of assent." See RESTATEMENT (SECOND) OF CONTRACTS $§ 282$ (1979) (neglecting to discuss the potential conflict with the silent acceptance rule in any comment).

274. A.L.C., supra note 265; see also MiLSOM, supra note 46, at 136 (explaining the London custom of concessit solvere, which was used with foreign traders).

275. Glover, supra note 8, at 1122; Lockwood v. Thorne, 11 N.Y. 170, 173-74 (1854).

Between merchants at home, an account which as been presented and no objection made thereto after the lapse of several posts, is treated, under ordinary circumstances, as being by acquiescence a stated account. Between merchants in different countries a longer time is given, but if no objection be made, after several opportunities of writing have occurred, it is considered acquiescence.

Id. (citations omitted).

276. A.L.C., supra note 265. 
Attempts to make account stated conform to modern ideas of agreement are inadequate. They rely upon a legal fiction, in which modern consumers and banks follow the same custom as early-modern international merchants in London.

The absurdity of this position becomes most apparent if one reverses the positions of the consumer and the bank. If a consumer sends a statement of how much the consumer thinks the bank owes him, do both consumer and bank (1) expect the bank to review the statement in a timely manner, (2) expect the bank to notify the consumer in a timely manner if it disagrees with the statement, and (3) believe that silence by the bank means that the bank agrees with the statement and promises to pay the amount owing to the consumer? Clearly not. The wisdom of a rule that encourages anyone, consumer or bank, to send out statements in the hope of being ignored is questionable.

Having established that implied account stated violates the silent acceptance rule, how can this violation be explained? Historically, the explanation is simple enough: when implied account stated first became law, it simply enforced merchant customs. ${ }^{277}$ Today, that type of case would not offend the silent acceptance rule.

However, violations of the silent acceptance rule are harder to explain if account stated applies between non-merchants. One writer considered the problem in 1920, noting the existence of account stated: "[w]here an unsettled running account exists between two persons, if one sends to the other a statement of the account it is generally held that retention of this by the other party without any expressed objection will render the amount an account stated." 278 His solution was to conceptualize account stated as something closer to an evidentiary rule than a cause of action: "[i]t seems, however, that silence here operates rather as an evidential than an operative fact. It is a rebuttable admission against interest, not the conclusive acceptance . . .."279 This approach is in accordance with a few cases and the practices of a few states, as noted above, ${ }^{280}$ but it is not reflected in the way courts generally imply account stated from rendition and retention without objection of a statement of account.

The conflict therefore remains between the rule against silent acceptance and implied account stated. This conflict cannot be resolved purely by discarding the "agreement" conceptualization of account stated. This Article proposes that the conflict can be resolved only by reform. The

277. Id.; see also ANSON, supra note 45, at 35 (explaining that merchant custom would support written agreements when traditional consideration was present); MILSOM, supra note 46, at 136 (explaining the London custom of concessit solvere, which was used with foreign traders).

278. A.L.C., supra note 265, at 444.

279. Id.

280. See supra notes $275-76$ and accompanying text. 
concept of account stated must be confined so that it does not imply assent from silence beyond the boundaries generally set by contract law.

\section{Nature of "Implication" in Account Stated}

If the agreement explanation of account stated is problematic, what is the alternative? I argue that the answer lies in the nature of the implication in account stated: account stated began as an agreement, either express or implied in fact, but it is often treated by the courts as a quasi-contract. Today, account stated is usually treated like a quasi-contract when the debtor is silent, like an express contract when the debtor expressly assents, and like a contract implied in fact when the debtor makes part payment. The tension between these positions is most apparent in the New York case of Citibank (South Dakota) N.A. v. Brown-Serulovic in which the court doubted whether a small part payment is sufficient to imply assent from the part payment. ${ }^{281}$ The court in Brown-Serulovic concluded that a small part payment was insufficient. ${ }^{282}$ Yet, the plaintiff would have succeeded if it had been able to show the necessary facts in an account stated claim: a statement rendered and retained without objection. ${ }^{283}$ Part payment is somehow less a sign of agreement than total silence and inaction.

This confusion between contracts implied in fact and contracts implied in law is not unique to account stated. The same confusion also arises in quantum meruit cases. ${ }^{284}$ Even the phrase "contracts implied in law" is misleading because such "contracts" are really about restitution, not contract. $^{285}$

As in other areas, courts dealing with account stated use "implied" ambiguously. For example, a New York court held in one case: "defendant impliedly agreed to pay the amount indicated when she received and retained the monthly statements without objection within a reasonable period." 286 While another New York court held:

281. Citibank (S.D.) N.A. v. Brown-Serulovic, 948 N.Y.S.2d 331, 332 (App. Div. 2012).

282. Id.

283. Id.

284. Candace S. Kovacic, A Proposal to Simplify Quantum Meruit Litigation, 35 AM. U. L. REV. 547, 553-56 (1986).

285. Juli Loden, The Earth is Not Flat and "A Quasi Contract Is Not A Contract At All”, 11 TRANSACTIONS: THE TENN. J. OF BUS. LAW 167, 187 (2010) (observing that in the absence of a writsystem, there is no need to maintain the fiction that quasi-contracts are contracts). $C f$., Clare Dalton, $A n$ Essay in the Deconstruction of Contract Doctrine, 94 YALE L.J. 997, 1011 (1985) (concluding that the position that quasi-contracts are not contracts "obscures the fact that the finding of contractual implication is guided in the so-called 'private' sphere by the same considerations that dictate the imposition of quasi-contract").

286. Citibank (S.D.) N.A. v. Jones, 708 N.Y.S.2d 517, 519 (App. Div. 2000). 
[W] hile the mere silence and failure to object to an account stated cannot be construed as an agreement to the correctness of the account, the factual situation attending the particular transactions may be such that, in the absence of an objection made within a reasonable time, an implied account stated may be found. ${ }^{287}$

The first statement means that assent is implied in law: the court inferred that the Defendant agreed to pay the debt merely by receiving the monthly statements and not objecting to them. The court made this inference not because the facts indicate actual assent, but because the law deems them to be assent. The second statement indicates an implied in fact approach: the implication is not drawn automatically, but it depends on the circumstances. In the right circumstances an implication is drawn from silence. The second statement unfortunately fails to further describe the circumstances in which an implication-in-fact should be made.

Is implied account stated "implied in fact" or "implied in law"? The current answer is that it is implied in law. Rendition of the account followed by retention without objection is all that is required for account stated to be implied in law.

The arguments against the expansion of account stated beyond the mercantile class and the modern policy arguments are united by their focus on the fictional nature of the implied account stated. The West Virginia Supreme Court in McGraw thought that to imply an account stated would be to "pretend."288 The Pennsylvania Court of Common Pleas in Clevenstine listed the reasons why it is fictional to imply assent from rendition and silence in the circumstances of a modern consumer-bank relationship. $^{289}$

Therefore, this Article's argument is not against any implied account stated, but only against implication by law regardless of circumstances. Having shown the existence of the fiction, its origins, present use, and policy criticisms, the question remains — what can be done about it?

\section{The Merchant Rule Must Return}

The solution to both the policy and the theoretical problems of implied account stated is simple: make implied account stated implied in fact by abolishing the implication of assent from silence. Instead, the implication of assent from silence should be a rule solely between businessmen for whom

287. Bank of Am., N.A. USA v. Hyatt, No. 2008-1655, 2011 WL 3689374, at*1-2 (N.Y. App. Term Aug. 16, 2011) (internal quotation marks omitted) (quoting Yannelli, Zevin \& Civardi v. Sakol, 749 N.Y.S.2d 270, 270 (App. Div. 2002).

288. McGraw v Traders Nat'l Bank, 63 S.E. 398, 400 (W. Va. 1908).

289. Capital One v. Clevenstine, 7 Pa. D. \& C.5th 153, 157-58 (Ct. Com. Pl. 2009). 
silence is generally considered acceptance. ${ }^{290}$ This change would remove the automatic assumption of assent from set facts which makes implied account stated a legal fiction in consumer collection cases. This change would also bring account stated back into the theoretical fold of true contracts. This change would not even prevent the implication of account stated in deserving circumstances that actually imply assent; ${ }^{291}$ it would simply make that implication akin to the more familiar implication of a contract in fact. The idea that acceptance by silence in the face of an invoice is an accepted mercantile custom still has some currency ${ }^{292}$ particularly in international trade. ${ }^{293}$ The Uniform Commercial Code includes a similar rule in section 2-207(2): the assent of an offeror to additional terms proposed by the offeree is presumed where the offeror fails to object within a reasonable time. ${ }^{294}$ The rule is explicitly limited to merchants. ${ }^{295}$ Both parties would reasonably expect the implication of assent in business relationships where the custom exists.

This change could be achieved in one of three ways. First, state courts in states like Maryland or West Virginia, could enforce the merchant requirement since the requirement was either never considered or was explicitly preserved. The courts could refuse any case except between merchants or their modern analogues. The meaning of "merchant and merchant" could reasonably be stretched to include other businesses or persons acting in a business capacity, but not consumers. This approach would effectively prevent the automatic implication of account stated in consumer collection actions. While this solution has the advantage of following prior decisions, it lacks a sound theoretical basis: the merchant rule itself does not resolve whether account stated must adhere to contract

290. Assuming, arguendo, that such a class of businessmen and such a practice still exists.

291. E.g., Nw. Motors, Ltd. v. James, 788 P.2d 584, 588 (Wash. Ct. App. 1990) (holding that manifesting acceptance of an amount due is an account stated, although it is not entirely clear if this is really a case of implied in fact or express assent).

292. Almost exactly the words of account stated are found in a modern description of the "commercial fact that acceptance plus silence for an unreasonable time most likely spell acceptance not only in legal satisfaction but in actual satisfaction of the contract as understood by the parties." Am. Bar Ass'n, An Apraisal of the March 1, 1990, Preliminary Report of the Uniform Commercial Code Article 2 Study Group, 16 DEL. J. CORP. L. 981, 1268 (1991) (emphasis in original) (referring to failure to object to delivery of defective bulk transfers).

293. For example, the Iran-U.S. Claims Tribunal use implied account stated in determining claims, characterizing it as "a well-established general principle in various legal systems that in commercial relationships one party may be obligated to pay another party ... a sum specified in an invoice if it receives the invoice but does not object to it within a certain period of time." John R. Crook, Applicable Law in International Arbitration: The Iran-U.S. Claims Tribunal Experience, 83 AM. J. INT'L. L. 278, 296 (1983) (emphasis added) (internal quotation marks omitted) (quoting Dames \& Moore v. Iran, Award No. 97-54-3, 1983 WL 233294, at*8 (Iran U.S. Cl. Trib. 1983)).

294. LARRY LAWRENCE, LAWRENCE'S ANDERSON ON THE UNIFORM COMMERCIAL CODE § 2207:119 (3rd ed. 2012).

295. Id. 
principles. Questions would still remain about the breadth of the class between whom account stated would apply without a principle for identifying class members.

Second, state courts that have not endorsed the use of account stated in consumer collection actions could continue to do so based on its inconsistency with modern contract principles. This would require a holding that an account stated can be implied from retention without objection only where an exception to the rule against silent acceptance already exists. In effect, such a decision would allow only an implied-infact account stated. This approach would have the same effect as the first approach, and would result in a more theoretically consistent contract law, which might more accurately identify the situations where implication of assent from silence is appropriate. Account stated could be implied in accordance with a wider, more modern merchant requirement, which conforms to the silent assent exceptions in the Restatement (Second) of Contracts.

Third, state legislatures could reform the substantive law of account stated in either of the above ways. Legislative intervention has the advantage of being clear, public, and conclusive. However, this issue seems unlikely to gain legislative attention.

\section{CONCLUSION}

Account stated threatens the welfare of consumers in two ways: it reduces the evidence required to obtain a judgment against a consumer in a collection action and, in certain cases, it allows collectors to evade statutory controls on debt collection and contracting. The solution to the second problem is simple: judges must not allow themselves to be carried away by the idea that account stated creates fresh liability. Account stated has always required some genuine underlying transaction. When statutes seek to regulate consumer transactions, those statutes must preempt actions relying on an account stated theory. Otherwise, account stated will be a tool for the evasion of consumer protection statutes.

The first problem is a much more substantial one, but its solution is as simple: implied account stated must not be permitted in consumer collection actions. This Article has presented three arguments against the use of account stated in consumer collection actions: (1) the historical argument, that account stated was limited to disputes between merchants and in some states this limitation remains good law; (2) the policy argument, that account stated is bad for consumer protection and its assumptions about consumer behavior are wrong; and (3) the theoretical argument, that implied account stated is inconsistent with the fundamental 
principles of modern contract law. Each argument supports the others. The historical origin of implied account stated is consistent with modern principles about silent acceptance, and it demonstrates that the basic assumptions underlying implied account stated are those of commercialnot consumer - dealings. The modern principles of contract law show that the use of account stated in consumer actions is exceptional, while its historical uses were not. Finally, the policy argument demonstrates the need for the judiciary and legislature to act to prevent the misuse of account stated.

The overwhelming advantage of a simple prohibition of implied account stated in consumer collection actions lies in a fact of modern collection suits: consumers rarely defend them. In the vast majority of the cases, courts are left to decide whether the plaintiff's case is sufficient to obtain judgment without argument from the defendant. Therefore, implied account stated allows plaintiffs to produce less evidence in a venue where they are unlikely to be challenged and still obtain judgment. Removing implied account stated entirely from the plaintiffs' pleading menu would affect the court's decision-making process, and plaintiffs would be left to plead breach of contract and provide the requisite evidence.

The resurrection of account stated has been a success, at least for plaintiffs in collection actions. However, its evidence-reducing qualities make it part of the broken system of debt collection, which fails to sufficiently protect consumers. It is not, as Bucci claimed, a clear and equitable rule, ${ }^{296}$ but a harsh and archaic one, with significant variations between states. Implied account stated favors seventeenth century trade practice over contemporary principles. Its application to consumers is unfair and, to the consumers at least, unexpected. It is time to amend this part of the broken debt collection system and put account stated in its place as part of modern contract law. 